\title{
The SEC and the Financial Industry: Evidence from Enforcement Against Broker-Dealers
}

\author{
By Stavros Gadinis*
}

The Securities and Exchange Commission plays a central part in the U.S. regulatory framework for the supervision of the financial industry. How has the SEC carried out this mission? Despite recurrent crises, systematic studies of SEC performance data are surprisingly scarce. As the SEC reforms itself to address the shortcomings revealed in 2007-2008, a systematic examination of the agency's past record can help identify priorities and evaluate the agency's renewed efforts. This study takes a first step in studying empirically SEC enforcement against investment banks and brokerage houses, examining the agency's record in the period right before the 2007-2008 crisis. This data suggests that defendants associated with big firms fared better in SEC enforcement actions as compared to defendants associated with smaller firms in three important dimensions. First, SEC actions against big firms were more likely to involve corporate liability exclusively, with no individuals subject to any regulatory action. Second, big-firm defendants were more likely to end up in administrative rather than court proceedings, controlling for types of violation and levels of harm to investors. Third, within administrative proceedings, big-firm employees were likely to receive lower sanctions, notably temporary or permanent bars from the industry. These patterns have important implications for major debates concerning corporate liability, regulatory capture, and the public and private enforcement of securities laws.

\footnotetext{
* Assistant Professor, Berkeley Law School. I thank Bill Allen, Robert Bartlett, Miriam Baer, Lucian Bebchuk, Jack Beermann, Margaret Blair, Lisa Bressman, Chris Brummer, Dick Buxbaum, Daniel Li Chen, Bob Cooter, Mel Eisenberg, Allen Ferrell, Tamar Frankel, Mira Ganor, Martin Gelter, Yehonatan Givati, Jack Goldsmith, Kent Greenfield, Todd Henderson, Howell Jackson, Lisa Junghahn, Marcel Kahan, Ehud Kamar, Louis Kaplow, Daniel Klerman, Donald Langevoort, William Latham, Katerina Linos, Michael Meurer, Zygmunt Plater, Amanda Rose, Ivan Reidel, Diane Ring, Hal Scott, Jasmin Sethi, Steve Shavell, David Sklansky, Holger Spamann, Richard Squire, Matthew Stephenson, Eric Talley, Steve Thel, Randall Thomas, Elina Treyger, Andrew Tuch, Charles Whitehead, and David Zaring, as well as workshop participants at the Harvard Law School Law \& Economics Seminar, the American Law \& Economics Association Conference 2008, the Conference on Empirical Legal Studies 2008, the Harvard Corporate and Securities Law \& Policy Seminar 2009, and the NYU Corporate Law Seminar 2010 , for valuable comments. I am deeply grateful to The Business Lawyer's Editor-in-Chief, Dixie Johnson, and to an anonymous peer reviewer for terrific suggestions. I also thank the Olin Center for Law, Economics, and Business at Harvard Law School and the Alexander S. Onassis Foundation for generous financial support.
} 


\section{INTRODUCTION}

Investment banks, brokerage houses, and their employees constitute one of the most controversial segments of the financial industry. In the past, they were praised as resourceful pioneers of financial innovation. ${ }^{1}$ After the collapse or nearcollapse of many illustrious brokerage houses (Bear Stearns, Lehman Brothers, Merrill Lynch), many see the investment banking and brokerage industry as excessive risk-takers who failed their clients' trust. ${ }^{2}$ Since U.S. securities law requires many of these financial institutions to register with the Securities and Exchange Commission ("SEC" or "the Commission") as broker-dealers, ${ }^{3}$ the SEC came under intense criticism in the wake of the recent financial crisis. ${ }^{4}$ The agency's then outgoing Chairman, Christopher Cox, publicly apologized for its enforcement shortcomings and called for internal review. ${ }^{5}$ His successor, Mary Schapiro, launched a significant redesign of the SEC's Division of Enforcement that was completed in $2010 .^{6}$

1. Structured finance gained significant praise for its risk-allocation potential and its ability to drive down companies' financing costs. See Claire A. Hill, Securitization: A Low-Cost Sweetener for Lemons, 74 WASH. U. L.Q. 1061 (1996); Steven L. Schwarcz, The Alchemy of Asset Securitization, 1 STAN. J.L. Bus. \& FiN. 133 (1994). Investment bankers were central in bringing about the innovative structured finance products. See Lynne L. Dallas, Short-Termism, the Financial Crisis, and Corporate Governance, 37 J. CoRP. L. 265, 284-85 (2012).

2. See, e.g., Margaret M. Blair, Financial Innovation, Leverage, Bubbles and the Distribution of Income, 30 Rev. BanKING \& FIN. L. 225 (2010); Richard Squire, Shareholder Opportunism in a World of Risky Debt, 123 HaRv. L. REv. 1151 (2010). For a discussion of investment banks' disclosure practices, particularly as to their exposure to derivatives risk, see Robert P. Bartlett, 111, Inefficiencies in the Information Thicket: A Case Study of Derivative Disclosures During the Financial Crisis, 36 J. Corp. L. 1 (2010). For a discussion of investment banks' impact on U.S. real estate markets, see Allen Ferrell \& Atanu Saha, Securities Litigation and the Housing Market Downtum, 35 J. CORP. L. 97 (2009).

3. The Securities Exchange Act of 1934 requires securities brokers and dealers to register with the Commission. 15 U.S.C. \$ $780(a)(1)$ (2006). According to the Act's statutory definitions, "brokers" are persons "engaged in the business of effecting transactions in securities for the account of others," while "dealers" are persons engaged in the business of buying and selling securities for their own account. 15 U.S.C. \& 78c(a)(4), (5) (2006 \& Supp. IV 2010). The Act provides some exceptions from the definition of "broker" and "dealer," most notably for certain bank activities. Id. \& 78c(a)(4)(B), (5)(C).

4. The SEC was the subject of intense criticism by the press, by Congress, and by its inspector general. See, e.g., Kara Scannell \& Susanne Craig, SEC Chief Under Fire as Fed Seeks Bigger Wall Street Role, WAll St. J., June 23, 2008, at A1. The public's reaction prompted the SEC's Office of Inspector General to examine the Commission's actions during the Bear Stearns collapse and issue scathing reports regarding the agency's failures. See OfFICE OF INSPECTOR GeN., U.S. SEC. \& EXCH. COMm'N, SEC's Oversight of Bear Stearns and Related Entities: The Consolidated Supervised Entity Program (2008), available at http://www.sec-oig.gov/Reports/AuditsInspections/2008/446-a.pdf; OFFICE OF Inspector Gen., U.S. Sec. \& Exch. Comm'n, SEC's Oversight of Bear Stearns and Related Entities: Broker-Dealer Risk Assessment Program (2008), available at http://www.sec-oig.gov/Reports/Audits Inspections/2008/446-b.pdf. The SEC's then-Director of Enforcement, Linda Thomsen, was prominent among several SEC staff members subjected to intense questioning in congressional hearings following the unraveling of the Madoff Ponzi scheme. See Assessing the Madoff Ponzi Scheme and Regulatory Failures, Hearing Before the Subcomm. on Capital Mkts. \& Gov't Sponsored Enters. of the H. Comm. on Fin. Servs., 11 th Cong. 59-87 (2009).

5. See Joanna Chung \& Greg Farrell, SEC Under Pressure on Failed Detection, Fin. TIMES, Dec. 18, 2008 , at 21.

6. The SEC's annual reports chronicle the key initiatives comprising this new structure, such as the appointment of a new director, the establishment of five specialized units within the Division of Enforcement to focus on certain categories of products (Asset Management, Structured Products, and 
But what exactly was the SEC's enforcement record toward broker-dealers before the crisis, and what are the dimensions in which the agency should strive to improve its performance? So far, we lack a comprehensive public account of SEC enforcement efforts against this segment of the financial industry. ${ }^{7}$ Most publicly available studies on SEC enforcement of broker-dealer regulation date from the 1970s, when the remedies and procedural options available to the agency were significantly more limited than today. ${ }^{8}$ Early studies identified the crucial role of broker-dealers as gatekeepers ensuring the accuracy of companies' public disclosures. ${ }^{9}$ But researchers complained about the opaqueness of SEC settlement negotiations, which prevented the development of a coherent jurisprudence of general applicability. ${ }^{10}$ The $2007-2008$ crisis brought SEC supervision of the broker-dealer industry to the forefront of national attention. More recently, federal courts joined the criticism against SEC settlement practices, when Judge Rakoff rejected the SEC's initial proposal in an action against Bank of America for faulty disclosure

Municipal Securities and Pensions) and securities law violations (Market Abuse and Foreign Corrupt Practices Act violations), and the efforts to integrate better compliance examinations and inspections with enforcement efforts. See U.S. Sec. \& ExCh. Comm'n, 2009 Performance and Accountability Report 8, available at http://www.sec.gov/about/secpar/secpar2009.pdf; U.S. SEC. \& EXCH. COMM'N, FY 2010 PERFORMANCE AND ACCOUNTABILITY REPORT 10-11, available at http://www.sec.gov/about/secpar/secpar2 010.pdf; U.S. SeC. \& Exch. COMm'N, FY 2011 Performance and Accountability Report 12-13, available at http://www.sec.gov/about/secpar/secpar2011.pdf [hereinafter 2011 Performance AND AccountabiLITY REPORT]. For a comprehensive overview of these reforms, see Robert Khuzami, Dir., Div. of Enforcement, U.S. Sec. \& Exch. Comm'n, Remarks at SIFMA's Compliance and Legal Society Annual Seminar (Mar. 23, 2011), available at http://www.sec.gov/news/speech/2011/spch03231 lrk.htm

7. Although the SEC has previously conducted internal reviews of its enforcement activities, results have not always been made available to the public. For example, the SEC conducted an internal top-to-bottom review of its enforcement division in 1998, led by then-Commissioner Laura Unger. According to press reports, the review identified delays in bringing new cases and completing existing ones, although specific results were not made public. See Judith Burns, SEC EnforcementUnit Speedup Gets High Marks, WALl ST. J., July 23, 1999, at Al. According to Unger, the results of this review and her general recommendations prompted subsequent SEC Chairman Harvey Pitt to press for a policy of "real-time enforcement." See Interview by Kenneth Durr with Laura Unger (SEC Historical Soc'y Nov. 7, 2005). For a recent empirical study of the performance of the Office of Thrift Supervision, see Dain C. Donelson \& David Zaring, Requiem for a Regulator: The Office of Thrift Supervision's Performance During the Financial Crisis, 89 N.C. L. Rev. 1777 (2011).

8. The Dodd-Frank Act required the SEC to conduct a study on the standards of care applied by broker-dealers and investment advisers in their dealings with retail customers and, more generally, evaluate the effectiveness of the U.S. legal framework on providing personalized advice and recommendations to retail customers. See U.S. SeC. \& EXCH. COMm'n, STudy On Investment Advisers AND BROKER-DeALERS (2011), available at http://www.sec.gov/news/studies/2011/913studyfinal.pdf. The SEC's study provides a wealth of information about the agency's enforcement processes, but does not enter into an analysis of individual cases' outcomes, as this article does. For a discussion of the implication of the Dodd-Frank Act for the fiduciary duties of brokers and dealers, see Tamar Frankel, The Regulation of Brokers, Dealers, Advisers, and Financial Planners, 30 Rev. Banking \& FIN. L. $123(2010)$.

9. See generally William L. Yerkes, Shelf Registrations: The Role of the Broker-Dealer, 29 Bus. LAw. 397 (1974) (arguing that broker-dealers' gatekeeping function grows in importance as securities laws introduce speedier registration procedures).

10. See Robert B. Martin, Jr., Broker-Dealer Manipulation of the Over-the-Counter Market-Toward A Reasonable Basis for Quotations, 25 Bus. Law. 1463, 1463 (1970); Fredrich H. Thomforde, Jr., Negotiating Administrative Settlements in SEC Broker-Dealer Disciplinary Proceedings, 52 N.Y.U. L. Rev. 237, 238 (1977). 
to investors regarding its merger with Merrill Lynch. ${ }^{11}$ In a later case, Judge Rakoff chastised, among other things, the agency's willingness to bring cases to closure through settlement by agreeing to defendants neither admitting nor denying wrongdoing. ${ }^{12}$ However, academic commentators have largely ignored this area of the law in the last two decades, despite continuous practitioner interest.

This article presents the first systematic empirical evidence of SEC enforcement practices toward broker-dealers in the last three decades. It constructs a new dataset of all SEC actions against broker-dealers in 2005, 2006, and the first four months of 2007. Because Republican administrations governed during those years, the dataset also includes all actions brought in $1998 .{ }^{13}$ The article synthesizes the agency's case-by-case approach to reveal systematic data on the types of violations the SEC penalizes, the defendants it pursues, the typical sanctions it imposes, and the enforcement venues and settlement patterns in its actions. This data provides valuable insights into the SEC's rationale for enforcement actions against, and remedies imposed on, finance industry professionals and their legal representatives who deal with the agency on a regular basis.

As this data suggests, the SEC faces three key decisions when formulating an enforcement action. One decision concerns whether to focus on the violations of individual employees of financial institutions, pursue the corporate entity that employees them, or charge them both. The data reveals that actions against big broker-dealers were more likely to target exclusively the corporate entity, without any further action against either frontline employees or high-level supervisors. More specifically, 40 percent of all actions against big broker-dealers involved exclusively corporate liability, compared to just 10 percent for smaller firms. ${ }^{14}$

A second major decision for the SEC involves the choice between a civil action and an administrative proceeding. As to broker-dealer violations, both enforcement venues are open to the Commission. ${ }^{15}$ However, this article shows that courts are a worse forum for finance professionals, since, when a violation occurs, a court injunction is more likely than an administrative action to result in a ban from the securities industry for defendants. ${ }^{16}$ The article finds that, for the same violation and comparable levels of harm to investors, big firms and their employees were more likely than smaller firms to avoid courts and face administrative proceedings instead. These differences between courts and administrative proceedings might gain special importance if the SEC shows increased preference toward administrative proceedings in response to the recent setbacks it has faced in federal court. ${ }^{17}$

11. Judge Rakoff later approved a settlement after the agency and the company agreed to higher sanctions. See infra note 20.

12. See SEC v. Citigroup Global Mkts., Inc, No. 11 Civ. 7387 (JSR), 2011 WL 5903733 (S.D.N.Y. Nov. 28, 2011).

13. 1998 was chosen as the most recent pre-election year of the last Democratic administration. For a more detailed discussion of the years selected for this article and the data collection more generally, see infra Part IIl.A.

14. See infra Part IV.A.

15. See infra Part Il.C.

16. See infra Part III.B.3.

17. For an example of these setbacks, see infra note 20. 
Third, the article turns to administrative cases-in which the SEC's claims arguably might carry more weight compared to court cases-to examine the type of sanctions the SEC pursues. ${ }^{18}$ Again, the article finds that, for the same violation and comparable levels of harm to investors, big firms and their employees were less likely to receive a ban from the securities industry, compared to small firms and their employees. ${ }^{19}$ The differential treatment of individual employees in large firms compared to individual employees in small firms is harder to justify from a public policy perspective.

This concrete examination of pre-crisis SEC enforcement toward a key segment of the financial industry reveals important trends and potential shortcomings in the agency's enforcement record and confirms certain criticisms against the SEC, while it alleviates others. For example, the article demonstrates a systematic lack of action against individual violators in high-profile cases, a criticism raised against the SEC's settlements most recently by Judge Rakoff. ${ }^{20}$ On the other hand, the article shows that the SEC did not conduct "rulemaking by adjudication" by using administrative proceedings for sophisticated violations, as some had feared. Moreover, this article's analysis provides essential information for a comparison between the SEC of 2007 and the redesigned agency of 2011. While sufficient time has not yet passed for a full evaluation, this article's data represents a benchmark against which the agency's renewed efforts in this area can be assessed.

More generally, the article's detailed portrayal of SEC enforcement against this segment of the financial industry has implications for three fundamental theoretical debates that have dominated academic interest in recent years: the role of corporate liability in securities enforcement, the impact of limited bureaucratic resources and employees' incentives to leave the agency for private firms, and the ultimate role of public and private enforcement in securities regulation.

Corporate liability has an important role to play in securities enforcement because, compared to individual violators, financial institutions may have more resources available to compensate victims and may be better placed to implement compliance programs. Yet, some theorists argue that corporate liability alone may be an imperfect deterrent when the firm cannot pass on the full impact of

\footnotetext{
18. The SEC has long been aware of this risk; in 1990, then-SEC Commissioner and nowChairman Mary Schapiro headed a Task Force on Administrative Proceedings to ensure that litigants have adequate information. See Task Force on Administrative Proceedings, SEC News Digest 1 (July 19 , 1990), http://www.sec.gov/news/digest/1990/dig071990.pdf. The SEC has tried to address this risk in various ways, such as by amending its Rules of Practice. See Rules of Practice, 60 Fed. Reg. 32738, 32738 (June 23,1995 ) (to be codified in scattered sections of 17 C.F.R.).

19. See infra Part IV.D.

20. SEC v. Bank of Am. Corp., 653 F. Supp. 2d 507, 508-09 (S.D.N.Y. 2009) (denying proposed settlement). Under the terms of the initial proposed settlement, Bank of America agreed to a $\$ 33$ million fine. $I d$. at 508 . Judge Rakoff later agreed to approve a settlement that proposed a $\$ 150$ million fine to be distributed to Bank of America shareholders who held stock at the time of the problematic disclosures. SEC v. Bank of Am. Corp., No. 09 Civ. 6829 (JSR), 2010 WL 624581, at *5-6 (S.D.N.Y. Feb. 22, 2010). The current SEC administration highlights cases where it brought actions against individual violators in its annual reports. See, e.g., 2011 Performance and AcCountability Report, supra note 6 , at 13-16.
} 
regulatory sanctions to employees who violate securities laws. ${ }^{21}$ For example, firms cannot ban finance professionals from the industry and prevent them from finding alternative employment or from starting their own ventures. This article shows that, in the cases discussed here, the SEC relied on exclusive corporate liability for 40 percent of actions against big-firm defendants. Many of these cases concerned violations not substantially different from other cases where the SEC chose to pursue individuals. In some, it is clear that individual violators had been identified, but were not named. The SEC's frequent reliance on exclusive corporate liability in enforcement cases against this segment of the financial industry raises important questions about optimal deterrence..$^{22}$

A second debate about SEC performance concerns the impact of limited bureaucratic resources and tight connections with the industry on agency policies. In a report issued after the crisis, the U.S. Government Accountability Office focused on the SEC's constrained bureaucratic resources, as the agency's staff levels have remained stable in a period of rapid growth for the financial industry. ${ }^{23}$ In addition, many are concerned that SEC decisions may be unduly influenced by the constant stream of SEC bureaucrats leaving the agency for more lucrative positions in the financial industry after only a few years of public service. ${ }^{24}$ Critics of SEC policies claim that broker-dealers form a powerful and well-resourced interest group that can sway regulation to its advantage..$^{25}$ Instead, proponents of SEC regulation argue that the agency has largely remained focused on its mission. ${ }^{26}$

21. See infra Part VI.A.

22. For a recent discussion of optimal deterrence in securities fraud and the SEC's efforts in this respect, see Amanda M. Rose, The Multienforcer Approach to Securities Fraud Deterrence: A Critical Analysis, 158 U. PA. L. Rev. 2173 (2010)

23. See U.S. Gov't accountabuluty Office, Securmties \& Exchange Commission: Greater Attention NeEded to Enhance Communication and Utilization of Resources in the Division of Enforcement 4-5 (2009), available at http:/www.gao.gov/new.items/d09358.pdf

24. Donald Langevoort sees the high rate of turnover among SEC officials as a key institutional trait of the agency. See Donald C. Langevoort, The SEC as a Lawmaker: Choices About Investor Protection in the Face of Uncertainty, 84 WASH. U. L. REV. 1591, 1598 (2006). John Coates also highlights that many SEC chairmen and other leading officials have roots in the financial industry. See John C. Coates IV, Private vs. Political Choice of Securities Regulation: A Political Cost/Benefit Analysis, 41 VA. J. INT'L L. 531, $563(2001)$.

25. Macey and Haddock argued that interest group lobbying can explain the SEC's failure to implement the congressional mandate to build a national market system for securities trading that emanated from section 11A of the Securities Exchange Act of 1934, 15 U.S.C. § 78k-1 (2006). See Jonathan R. Macey \& David D. Haddock, Shirking at the SEC: The Failure of the National Market System, 1985 U. ILL. L. REv. 315,316 . In a later article, Macey connects reforms in commercial banking and insider trading regulation to the objectives of interest groups within the financial industry. See Jonathan R. Macey, The Myth of "Reregulation": The Interest Group Dynamics of Regulatory Change in the Financial Services Industry, 45 WASH. \& LeE L. Rev. 1275, 1277 (1988). Adam Pritchard is concerned that the SEC, because of its character as an independent agency, is "vulnerable to the political whims of key legislators." See A.C. Pritchard, The SEC at 70: Time for Retirement?, 80 NotRE DAME L. ReV. 1073, 1076 (2005).

26. See Joel Seligman, The Historical Need for a Mandatory Corporate Disclosure System, 9 J. CoRP. L. 1, 9 (1983); John C. Coffee, Jr., Racing Towards the Top?: The Impact of Cross-Listings and Stock Market Competition on International Corporate Governance, 102 CoLUM. L. Rev. 1757, 1780 (2002) (arguing that vigorous enforcement of strong legal standards by the SEC attracts foreign issues into the U.S. stock markets); Robert A. Prentice, The Inevitability of a Strong SEC, 91 CORNELL L. Rfv. 775, 775 (2006) (claiming that strong SEC regulation is justified on the basis of evidence in behavioral psychology regarding investor conduct in stock trading). 
This article makes some critical first steps in understanding SEC performance. The data suggests that lower sanctions for big firms and their employees did not result from the privileged treatment of a few high-profile Wall Street firms with strong political connections. Instead, big firms (and their employees) uniformly faced lower sanctions than small firms and their employees. This finding is consistent with arguments emphasizing the lack of bureaucratic resources and the agency officials' tight connections with the industry, but can also be explained in other ways. However, publicly available data does not permit further testing of these two hypotheses, since the identity of the SEC officials who participate in settlement negotiations or handle administrative proceedings is not known in most cases. Thus, the article calls for the SEC to release that data for these administrative proceedings and settlements in the future, as it already does for court actions. ${ }^{27}$ While additional disclosure may push SEC employees into the public limelight when bringing administrative enforcement actions and negotiating settlements, it can help increase the SEC's accountability toward the investment community and restore confidence in the agency's efforts.

The detailed portrayal of SEC enforcement activity against a significant segment of the financial industry in this article also supplements a wider literature in securities regulation about the effectiveness of public regulators, such as administrative agencies, and of private enforcement efforts through investor lawsuits. In comparative studies, some scholars associate capital market growth with the availability of strong private enforcement mechanisms in a country's legal system, but only see modest results when public regulators are granted extensive formal powers. ${ }^{28}$ However, subsequent studies examining the resources that countries actually devote to public enforcement - such as higher budgets or more employees-find that greater spending is also associated with superior capital markets outcomes. ${ }^{29}$ This article takes a further step in the empirical study of public enforcement by offering a nuanced account of how public regulators use the resources and legal tools they are granted.

In the U.S. literature, prior empirical studies evaluating the efficacy of the securities enforcement regime have examined in great detail questions related to consumers of financial services, such as corporations issuing stock, in the context of public offerings and securities class actions. ${ }^{30}$ However, this discussion cannot be complete without examining enforcement against providers of financial services,

27. In court actions, SEC complaints include the names of key SEC officials in the litigation team representing the agency, who also participate in settlement negotiations with defendants. The litigation team is likely to be different than the SEC officials who investigated the case and recommended the initiation of the action. When the SEC picks the administrative route, particularly when the agency initiates an action and simultaneously accepts a settlement offer, the SEC officials handling both the investigation and the settlement are more likely to be the same.

28. See generally Rafael La Porta, Florencio Lopez-De-Silanes \& Andrei Shleifer, What Works in Securities Laws?, 61 J. Fin. 1 (2006).

29. See Luzi Hail \& Christian Leuz, International Differences in the Cost of Equity Capital: Do Legal Institutions and Securities Regulation Matter?, 44 J. ACCT. RES. 485, 486 (2006).

30. See generally Stephen J. Choi, Do the Merits Matter Less After the Private Securities Litigation Reform Act?, 23 J.L. ECON. \& ORG. 598 (2006) (studying the effect of PSLRA on class actions for securities fraud); James D. Cox, Randall S. Thomas \& Dana Kiku, SEC Enforcement Heuristics: An Empirical Inquiry, 53 DukE L.J. 737 (2003) (examining the overlap between private securities class actions and 
such as broker-dealers. The SEC actions against broker-dealers, which this article analyzes, are a major part of enforcement against this segment of the financial industry. This article does not cover disciplinary actions brought by the Financial Industry Regulatory Authority ("FINRA"), nor client lawsuits. Data from these additional venues would further the inquiry this study begins.

Part II of the article provides background on the SEC enforcement process. Part III examines data and summary statistics regarding court and administrative cases and presents the typical sanctions for broker-dealer violations. Part IV presents the main analysis indicating that big-firm defendants fare better in SEC enforcement actions, and discusses robustness checks and limitations of the analysis. As an additional robustness check, Part V investigates qualitative similarities and differences between big and small-firm misconduct through a case study focusing on a single violation, failure to supervise. Part VI offers a discussion of this article's implications for theoretical debates in corporate and securities law, and Part VII concludes.

\section{Overview of the SEC Enforcement Process}

The federal securities laws provide the SEC with wide discretion in formulating enforcement actions. Because the early stages of SEC investigations often involve little formality and no public announcement, the SEC staff plays a critical role in handling this first phase of the enforcement process. The five-member Commission heading the agency frequently becomes involved only after the staff finalizes proposals for specific actions. ${ }^{31}$ In many cases, the staff's recommendations to the Commission will include settlement terms already discussed with firms targeted in the investigations.

\section{A. SEC Monitoring of Broker-Dealer Compliance}

The SEC oversees broker-dealers' compliance with its requirements through its inspection and examination program. The Securities Exchange Act of 1934 ("Exchange Act") authorizes the SEC to conduct inspections of broker-dealers'

SEC enforcement actions against corporate issuers); James D. Cox, Randall S. Thomas \& Dana Kiku, Does The Plaintiff Matter? An Empirical Analysis of Lead Plaintiffs in Securities Class Actions, 106 Colum. L. REv. 1587 (2006) (examining the impact of a PSLRA provision that places as lead plaintiff the party with the greatest financial interest); Allen Ferrell, Mandatory Disclosure and Stock Returns: Evidence from the Over-the-Counter Market, 36 J. LEGAL STud. 213 (2007); Howell E. Jackson \& Mark Roe, Public and Private Enforcement of Securities Laws: Resource-Based Evidence, 93 J. FIN. EcoN. 207 (2009) (arguing that public enforcement of securities laws is as important in explaining stock market growth as disclosure rules, and more important than private liability rules); La Porta, Lopez-de-Silanes $\&$ Shleifer, supra note 28 , at 1 (arguing that laws mandating corporate disclosure and enforcement of disclosure liability rules by private actors benefit stock market development); Robert B. Thompson \& Randall S. Thomas, The New Look of Shareholder Litigation: Acquisition-Oriented Class Actions, 57 VAND. L. REv. 133 (2004) (studying class actions filed under state law to challenge the conduct of corporate directors in the context of impending acquisitions). For a discussion of combined private and public rights of enforcement, see Matthew C. Stephenson, Public Regulation of Private Enforcement: The Case for Expanding the Role of Administrative Agencies, 91 VA. L. REv. 93 (2005).

31. In the period covered by this article's dataset, the five-member Commission could become involved in the enforcement process earlier, if the staff sought a formal order of investigation and a subpoena. This authority has since been delegated to the staff. See infra note 36. 
books and records, which in practice also include informal interviews with the broker-dealers' employees. ${ }^{32}$ Inspections are conducted by specially designated staff, separate from the SEC's enforcement officers, although an inspection may result in a referral to the Division of Enforcement. In addition, broker-dealers are subject to regular inspections by self-regulatory organizations ("SROs"), such as FINRA. Neither SEC nor SRO inspections are public.

Following major oversight failures in the mutual fund industry in 2003-2004, the SEC established a risk-based approach in choosing regulated firms for inspection. Under this approach, the SEC relies on broker-dealer inspections by selfregulatory bodies, annually reviewing a sample of firms previously inspected by SROs to ensure high inspection quality. ${ }^{33}$ In addition to sample reviews, the SEC itself inspects the twenty largest broker-dealers each year. ${ }^{34}$ The SEC also conducts special examinations when prompted by suspicions about specific firms or industry-wide practices. According to the SEC's Performance and Accountability Reports, inspections identify deficiencies in more than 80 percent of examinations of financial firms, but less than 10 percent of those instances result in a referral to enforcement staff for further investigation. ${ }^{35}$

\section{B. INVESTIGATIONS}

While inspections generally serve monitoring purposes, investigations seek to collect information about specific possible violations of federal securities laws. The SEC staff may start a preliminary investigation by opening a "matter under inquiry," to assess whether launching an investigation is appropriate. ${ }^{36}$ If available information indicates potential securities laws violations, the SEC staff can initiate an informal investigation without approval from the five-member Commission. ${ }^{37}$ However, a formal order of investigation is necessary in order to issue a subpoena. ${ }^{38}$ During the investigation, individuals and corporate entities may put forward potential settlement terms to the SEC staff.

32. Securities Exchange Act of 1934 \& 17(b), 15 U.S.C. \& 78q(b) (2006 \& Supp. IV 2010)

33. Then-SEC Director of Compliance, Lori Richards, explained how the market-timing scandals altered the agency's philosophy as to inspections and examinations in her public speeches. See, e.g., Lori Richards, Dir., Office of Compliance Inspections \& Examinations, U.S. Sec. \& Exch. Comm'n, An Update on the SEC's Examination Program, Speech at the Financial Services Institute: First Annual Public Policy Day (Oct. 13, 2004), available at http://www.sec.gov/news/speech/spch 101304lr. $\mathrm{htm}$. For a more detailed discussion of the SEC risk-based inspection and examination program, see U.S. Gov't Accountability Office, Securities and Exchange Commission: Steps Being Taken to Make Examination Program More Risk-Based and Transparent 7-8 (2007), available at http://www.gao.gov/new. items/d071053.pdf [hereinafter GAO REPORT ON Risk-Based Examinations].

34. GAO REPORT ON Risk-BASED EXaminations, supra note 33, at 8.

35. Id. at 22.

36. See U.S. SeC. \& Exch. Comm'n, Enforcement Manual 14 (Mar. 9, 2012), available at hitp://www. sec.gov/divisions/enforce/enforcementmanual.pdf [hereinafter SEC ENFORCEMENT MANUAL 2012].

37. Id. at 14-15. As the SEC is an independent agency, the five-member Commission heading the agency consists of two Democrats, two Republicans, and a Chairman affiliated with the President's party.

38. Id. at 20. During the period covered by this article's dataset, only the five-member Commission could issue a formal order of investigation. See U.S. SEC. \& EXCh. COMm'N, Enforcement Manual 19 
At the close of the investigation, if the SEC staff is recommending formal action, it presents the Commission with any evidence of potential securities laws violations, and any proposed settlement terms. The Commission, convening in a non-public meeting that excludes potential defendants, ${ }^{39}$ considers the staff's recommendations, seeks input from its General Counsel ${ }^{40}$ and the heads of SEC divisions, including enforcement, reviews any Wells notices by the staff and any responses submitted by potential defendants, and decides whether and how to proceed against any violators. ${ }^{41}$

\section{Proceedings}

The SEC may formally initiate an enforcement action against a defendant in two ways. First, the Commission can bring a civil injunctive action in a federal district court, even if defendants have agreed to settle. Alternatively, the Commission can institute administrative proceedings against the defendant, which may culminate in a hearing before an Administrative Law Judge ("ALJ"), but in practice are often settled with the Commission at an earlier stage without ALJ involvement. In either case, the Commission can also refer cases to criminal authorities, SROs, or state regulators. Federal securities laws grant the Commission ample authority to bring either court ${ }^{42}$ or administrative proceedings ${ }^{43}$ against regulated entities, such as broker-dealer firms and their employees, thus allowing the agency wide discretion in choosing between the two venues with regard to these defendants. Effectively, the Commission can obtain identical sanctions against regulated entities in both venues, as Part II.D discusses below.

Administrative proceedings offer to defendants some key advantages as compared to civil courts, particularly with regard to the public release of information about the defendants' misconduct. In practice, the Commission often considers the staff's recommendations for initiating a court or administrative action, as well as the staff's suggestions for the defendants' offer of settlement, at the same meet-

(Oct. 6, 2008) thereinafter SEC Enforcement Manual 2008]. In 2009, under Chairman Schapiro, the Commission delegated this authority to the Director of Enforcement, initially for a one-year trial. The delegation was extended indefinitely in 2010. See 17 C.F.R. 8 200.30-4(a)(13) (2011). The authority was further sub-delegated to other senior SEC officers. See SEC ENFORCEMENT MANUAL 2012, supra note 36, at 20.

39. This article will use the term "defendants" to include both defendants in court proceedings and respondents in administrative proceedings, to limit inconvenience for the reader

40. The General Counsel is appointed directly by the SEC Chairman.

41. When the Commission is considering whether to institute enforcement proceedings, it convenes in a closed meeting. See 5 U.S.C. \$ 552(b) (2006 \& Supp. IV 2010); 17 C.F.R. \$ 200.402(a)(5) (2011); see also SEC EnforCement Manual 2008, supra note 38, at 29-30.

42. The Commission's authority to initiate injunctive proceedings is based on section 21 (d) of the Exchange Act, 15 U.S.C. \& 78u(d) (2006 \& Supp. IV 2010).

43. Section 15(b) of the Securities Exchange Act of 1934 authorizes the Commission to impose sanctions on broker-dealers who have willfully violated provisions of the securities laws, after notice and opportunity for a hearing. 15 U.S.C. \& 78o(b)(4) (2006 \& Supp. IV 2010). In the Commission's standard jurisprudence, "willfully" means intentionally committing the act that constitutes the violation. See Wonsover v. SEC, 205 F.3d 408, 414 (D.C. Cir. 2000); Tager v. SEC, 344 F.2d 5, 8 (2d Cir. 1965). There is no requirement that the actor also be aware that he or she is violating one of the securities rules or acts. 
ing. If the Commission decides to initiate an administrative proceeding, it can close the matter swiftly and, in the same procedural step, accept the proposed settlement terms without the need to obtain an ALJ's approval. While the Commission can also file and settle civil court actions the same day, it needs to obtain a judge's approval. Moreover, contested actions arise more often in civil courts. In those cases, the Commission typically issues multiple public releases, including the filing of the Commission's complaint and the announcement of the settlement. ${ }^{44}$ Thus, the negative publicity for defendants is repeated. Moreover, the settlement must win the court's approval. On some occasions, the Commission will proceed with filing charges in court against a defendant even though the defendant already has agreed to a settlement, often to underscore the egregiousness of the violations. ${ }^{45}$ However, court proceedings offer one advantage to defendants that might be exposed to private actions by investors in addition to any SEC enforcement efforts: they do not contain any judicial findings. In contrast, settlements in SEC administrative proceedings include findings that may be admissible in court in a related private action as an expert government report. ${ }^{46}$ Overall, contrary to traditional concerns that the SEC's double role as legislator and prosecutor might lead to harsh outcomes for defendants, ${ }^{47}$ in current SEC practice, administrative proceedings are actually beneficial for defendants agreeing to settle. In the past, there were concerns that ALJs may align themselves more closely with the SEC than would district court judges. ${ }^{48}$

\section{SANCTIONS}

In both courts and administrative venues, the SEC can obtain three types of sanctions against broker-dealers: orders prohibiting similar violations in the future; monetary sanctions, such as fines, disgorgement orders, and interest penalties;

44. For example, when the SEC brought a civil complaint against former employees of Kimberly Securities, it issued one press release to announce the filing of the complaint on August 30, 2004, Litig. Release No. 18860, 83 SEC Docket 2115, 2004 WL 1924214 (Aug. 30, 2004), and another release to announce the settlement, Litig. Release No. 19677, 87 SEC Docket 2724, 2006 WL 1140873 (Apr. 28, 2006).

45. In the rare broker-dealer cases where the SEC filed settled charges before a civil court, the language in the SEC release made clear that this extraordinary step reflected the egregiousness of the violations. See, e.g., SEC v. Friedman, Billings \& Ramsey Co., Litig. Release No. 19950, 89 SEC Docket 1913, $2006 \mathrm{WL} 3740315$, at * $1-2$ (Dec. 20, 2006). Out of the 310 court actions in the dataset, only twenty-eight involved filing of settled charges by the SEC.

46. Pursuant to Federal Rule of Evidence 801(c), statements made not while testifying at the current trial or hearing are not admissible into evidence as hearsay. However, according to Federal Rule of Evidence 803(8)(A)(iii), exceptions from the rule against hearsay include statements made by a public office if, among others, they constitute factual findings from a legally authorized investigation in a civil case or against the government in a criminal case. For a discussion of the contours of admissibility of government reports into evidence, see John D. Winter $\&$ Adam P. Blumenkrantz, The Admission of Government Agency Reports Under Federal Rule of Evidence 803(8)(c), Mass ToRTs (Am. Bar Ass'n Section of Litig.), Spring 2009, at 1.

47. See Roland L. Redmond, The Securities Exchange Act of 1934: An Experiment in Administrative Law, 47 YALE L.J. 622, 636-37 (1938).

48. See ABA Comm. on Fed. Regulation of Sec., Report of Task Force on the SEC Administrative Law Judge Process, 47 Bus. Law. 1731, 1734 (1992). 
and orders suspending or expelling defendants from the securities industry. All sanctions are available against both broker-dealer firms and individuals.

SEC civil actions in court seek to obtain an injunction prohibiting the defendant from violating securities laws in the future. ${ }^{49}$ Similarly, the Commission can issue cease-and-desist orders in administrative proceedings. ${ }^{50}$ Cease-and-desist orders are largely a public reprimand of the defendants' conduct. In addition, the Commission may seek equitable remedies such as an undertaking by the defendants to introduce reforms in their compliance process, or requiring retention of a consultant to perform further reviews. ${ }^{51}$

Monetary sanctions can take two forms. First, courts or the SEC may order the defendants to disgorge any profits illicitly acquired, including pre-judgment interest. ${ }^{52}$ In addition, the SEC may order defendants to pay a fine, or obtain from the court an order against the defendants to pay a fine. ${ }^{53}$ Disgorgement orders seek to deprive violators of their unjust enrichment, and civil fines aim at punishment or deterrence, rather than compensating victims. Nevertheless, the SEC typically distributes these funds to harmed investors. ${ }^{54}$

Finally, the SEC may prohibit defendants from offering brokerage services, either on a temporary or on a permanent basis. Firms' licenses may be temporarily suspended or permanently revoked, while individuals may be barred from the broker-dealer industry for a limited time or indefinitely. ${ }^{55}$ Expulsion from the in-

49. See supra note 42; see also, e.g. SEC v. Herman's World of Sports, Inc., Litig. Release No. 19388, 86 SEC Docket 824, 2005 WL 2318421 (Sept. 22, 2005).

50. Securities Exchange Act of 1934 \& 21C, 15 U.S.C. \& 78u-3 (2006 \& Supp. IV 2010). For examples of SEC cease-and-desist orders, see infra note 51.

51. See, e.g., In re J.P. Morgan Sec., Inc., Release No. 34-51200, 84 SEC Docket 2989, 2005 WL 354586, at *4 (Feb. 14, 2005) (defendant undertakes to introduce compliance reforms); In re Jeffries \& Co., Release No. 34-54861, 89 SEC Docket 1231, 2006 WL 3488900, at *12-14 (Dec. 1, 2006) (defendant undertakes to hire an outside compliance consultant).

52. The mechanism for distributing to investors funds retrieved through disgorgement orders was first codified by the Sarbanes-Oxley Act and became known as the "Fair Funds" provision. SarbanesOxley Act of 2002, Pub. L. No. 107-204, § 308, 116 Stat. 745,784 (codified at 15 U.S.C. \& 7246 (2006)). Fair Funds allowed the Commission to augment the disgorgement fund with any civil penalties ordered against the defendant, provided that disgorgement was also awarded. Id. This regime was in place during 2005, 2006, and 2007, three of the years covered in the dataset. Disgorgement orders included in 1998 actions could result in distributing funds to investors, but penalties could not be included in the funds, which could have affected the SEC's and the defendants' attitude toward those orders. The analysis in Part IV includes year-fixed effects, and the coefficients for those years should capture potential changes in attitude. The Dodd-Frank Act further amended the Fair Funds provision. Dodd-Frank Wall Street Reform and Consumer Protection Act, Pub. L. No. 111-203, § 929B, 124 Stat. 1376,1852 (2010) (codified at 15 U.S.C. $\$ 7246$ (Supp. IV 2010)). After these latest amendments, the Commission may add to the funds distributable to investors any amount retrieved through civil penalties, regardless of whether disgorgement has also been ordered. See 15 U.S.C. $\S 7246(a)$.

53. See, e.g., Certain Broker-Dealers Who Failed to File All or Part of Form BD-Y2K, Release No. 34-40573, 68 SEC Docket 543, 1998 WL 727244, at *3 (Oct. 20, 1998) (SEC administrative order imposing fine); SEC v. Herman's World of Sports, Inc., Litig. Release No. 19388, 86 SEC Docket 824 , 2005 WL 2318421, at *1-2 (Sept. 22, 2005) (SEC obtains court order against the defendants to pay fines).

54. See supra note 52.

55. The Securities Exchange Act of 1934 authorizes the Commission to suspend the registration of a broker-dealer for a period up to twelve months, or to bar the broker-dealer or firm from association 
dustry is the harshest penalty available to the Commission--it forces defendants to quit their current business activities and seek a new profession, which is likely to be substantially less lucrative. The formal authority to banish registered brokerdealer firms or their employees from the securities industry rests exclusively with the Commission, ${ }^{56}$ and thus courts cannot issue such an order directly. However, a court-issued injunction allows the SEC to initiate administrative proceedings to determine whether to impose such a ban on the defendants, if it finds such ban in the public interest. ${ }^{57}$ Typically, the SEC will impose a ban following a court injunction. ${ }^{58}$

\section{E. Individual and Corporate Liability}

The federal securities laws allow the SEC to bring enforcement actions against individual securities professionals who allegedly engaged in misconduct, against their employers-the brokerage firms and other financial institutions—or against both. Under section 20(a) of the Exchange $\mathrm{Act}^{59}$ and section 15 of the Securities Act of 1933 ("Securities Act"), ${ }^{60}$ persons in control of another person who has been found liable for violating the securities laws are also jointly and severally liable, unless they have acted in good faith. Compared to other employers, broker-dealers are subject to a more stringent good-faith standard ${ }^{\text {61: }}$ : they cannot invoke ignorance or negligent supervision to escape liability. Thus, they will be held liable when they have failed to supervise adequately their employees. ${ }^{62}$ Moreover, section 15 of the Exchange Act authorizes the Commission to sanction broker-dealers who have failed to prevent violations of securities laws by persons subject to their supervision. ${ }^{63}$ Broker-dealer firms may also be held liable for their employees' misconduct under general agency law principles. ${ }^{64}$

with broker-dealers or other regulated entities. See Securities Exchange Act of $1934 \S$ 15(b)(4), 15 U.S.C. \& 780 (b)(4) (2006 \& Supp. IV 2010). Since a key difference between a ban and a suspension is the duration of the prohibition, this article will use the term "bar" or "ban" interchangeably also to include suspensions.

56. During the period covered in this dataset, the SEC had the authority to suspend or bar an employee of a broker-dealer firm from being associated with broker-dealers, but not with other regulated entities, such as investment advisers. The Dodd-Frank Act has extended the scope of the SEC's authority by allowing the agency to suspend or bar a violator from being associated with other regulated entities in addition to broker-dealers. See Securities Exchange Act of $1934 \& 15(b)(6)(A), 15$ U.S.C. $\S 780$ (b)(6)(A) (2006 \& Supp. IV 2010); Exchange Act § 15B(c)(4), 15 U.S.C. \$ 780-4 (2006 \& Supp. IV 2010); Exchange Act $\$ 17 A(c)(4)(C), 15$ U.S.C. $\$ 78 q-1(c)(4)(C)$ (2006 \& Supp. IV 2010); Investment Advisers Act of 1940 \$ 203(1), 15 U.S.C. § 80b-3 (2006 \& Supp. IV 2010)

57. Exchange Act $\$ 15(b)(4)(C), 15$ U.S.C. \& $780(b)(4)(c)$.

58. See infra Part lli.B.3.

59. 15 U.S.C. $\$ 78 \mathrm{t}(\mathrm{a})(2006 \&$ Supp. IV 2010).

60. 15 U.S.C. \& 770 (2006 \& Supp. IV 2010).

61. See Lewis D. Lowenfels \& Alan R. Bromberg, Controlling Person Liability Under Section $20(a)$ of the Securities Exchange Act and Section 15 of the Securities Act, 53 Bus. Law. 1, 3 (1997); see also Loftus C. Carson, II, The Liability of Controlling Persons Under the Federal Securities Acts, 72 NotRe Dame L. Rev. 263, 315 (1997).

62. See Thomas lee Hazen, Law of Securities Regulation 499 (6th ed. 2009).

63. 15 U.S.C. $\$ 78-o(b)(4)$ (2006 \& Supp. IV 2010)

64. See id. 


\section{Violations, Sanctions, and Settlement: Data and Summary Statistics}

\section{A. DAtA}

The article uses data on SEC enforcement actions collected and coded from the agency's administrative and litigation releases, available on its website. Administrative releases contain in full the ALJ's decision or the order issued by the agency following a settlement. Litigation releases summarize the court's order and findings. ${ }^{65}$ The dataset includes all SEC enforcement actions against brokerdealers, for any violation of the securities laws, finalized in 1998, 2005, 2006, and the first four months of 2007. 1998 was chosen to allow for variation in SEC enforcement policies under Democratic and Republican administrations. ${ }^{66}$ More specifically, the dataset includes only complaints that, in the period in question, resulted either in a settlement between the SEC and the defendant(s) or in a finding of violation against the defendants, as well as any sanctions sought. The violations recorded are those indicated in the final court ruling, court settlement, ALJ decision, or Commission order. All other preliminary steps (e.g., subpoenas) or subsequent actions (e.g., fund distributions) are not recorded.

The SEC's releases provide information only for cases in which the agency formally initiated proceedings. Thus, the findings of the article, especially with regard to choice of venue between courts and administrative proceedings, should be viewed in light of our inability to observe cases in which the SEC did not initiate an action. Moreover, while the SEC website lists ALJ decisions that dismiss SEC actions, it provides incomplete information regarding SEC lawsuits dismissed in court. According to its annual reports, the SEC has a win rate of 90 percent or higher. ${ }^{67}$ Thus, the analysis focuses on cases that have resulted in some finding of violation.

When an enforcement action concerns multiple defendants, each defendant is treated as a separate observation because defendants may differ in the type

65. The SEC issues releases in various stages during the enforcement process. I focus on releases that include an order by the SEC against defendants or notices of referrals to criminal authorities, such as the initiation of proceedings, the terms of settlement, or the court ruling. Because SEC practices as to issuance of litigation releases seem less strict in comparison to administrative ones, I have sometimes complemented litigation data with information from administrative releases issued by the Commission when considering whether the Commission imposed a ban following a court-issued injunction.

66. More specifically, 1998 was chosen because it was more than a year away from the presidential elections on November 7 , and the burst of the dotcom bubble, which might have presented uncharacteristic enforcement patterns. Moreover, U.S. financial markets in 2004 are more directly comparable to 1998 instead of an earlier year in the Clinton administration, such as 1994.

67. See U.S. SeC. \& Exch. Comm'n, 2007 Performance and Accountabiluty Report 27, available at http://www.sec.gov/about/secpar/secpar2007.pdf [hereinafter 2007 PerFormance AND ACCOUNTABILITY REPORT]. The SEC considers a case as "successfully resolved" if it obtains a judgment in its favor, a settlement, or a default judgment. Id. In other words, this win rate includes all cases in which the SEC obtained at least some relief. 
of their misconduct and the severity of their violations. ${ }^{68}$ The dataset includes observations for both corporate and individual defendants. Data on firms' characteristics, such as number of employees, listing, size, headquarter location, participation in a corporate group, and capital to assets ratios, are from the OneSource database, the Securities Industry Yearbooks, ${ }^{69}$ and FINRA's BrokerCheck database.

The article classifies as big firms those that had more than 1,000 employees, either in the United States or abroad, during the year in which the action was finalized.$^{70}$ Affiliates of big firms are also considered big, regardless of whether the parent company was active in broker-dealer services or in another segment of the financial industry. Where data on a firm's number of employees was not available in the above databases and could not be determined through other publicly available sources, firms are assumed to be small. To examine whether different measures of firm size affect the findings, the main analyses are repeated with two additional size classifications: first, all firms with 100 employees or more are classified as big, and second, all firms listed on a stock exchange, either within the United States or abroad, are classified as big. Information on whether a firm was listed on a stock exchange was readily available for all companies in the dataset.

\section{B. Summary Statistics}

The full dataset includes 545 enforcement actions for violation of broker-dealer registration provisions in the period covered in the sample, including 235 administrative proceedings and 310 court proceedings. Ninety-one court proceedings involved criminal liability exclusively ${ }^{71}$ and twenty-one court proceedings combined criminal and civil liability, while the remaining 198 court proceedings involved civil liability exclusively. All 235 administrative proceedings involved civil liability exclusively.

The summary statistics below bring to light key features of the SEC's overall enforcement policy toward the broker-dealer industry that confirm empirically some scholars' and practitioners' expectations but disconfirm others. More specifically, the following paragraphs present information about the distribution of violation types in administrative and court proceedings, the average bans and suspensions

68. The analysis in Part IV below takes into account whether other defendants involved in the same factual circumstances have been found to have violated U.S. securities laws, by examining defendants linked by the Commission in the same administrative or litigation release.

69. Now the Securities Industry and Financial Markets Association Yearbooks.

70. Distinctions between big and small firms are common in the literature. See, e.g., Ehud Kamar, Pinar Karace-Mandic \& Eric Talley, Sarbanes-Oxley's Effect on Small Firms: What Is the Evidence?, in IN THE NAME OF ENTREPRENEURSHIP? 143, 150 (Susan M. Gates \& Kristin J. Leuschner eds., 2007).

71. The SEC does not have authority to conduct criminal proceedings. However, the SEC has the authority to determine whether violators who have been found guilty in criminal courts should also receive a ban from the broker-dealer industry. Because this ban results directly from a court proceeding, it is classified here under "court proceedings." See supra Part II.D. 
per violation types, and the average monetary sanctions in both venues. This data shows that the SEC assigned fraud-based violations predominantly to courts, while violations relating to supervisory failures were more likely to result in administrative proceedings. However, few violations were assigned exclusively to one venue, suggesting that the SEC often exercised its discretion in choosing venues. Contrary to conjectures that the SEC would assign the most sophisticated violations to administrative proceedings to engage in "rulemaking by adjudication" or to secure a "home court advantage," the SEC distributed these violations evenly between the two venues. ${ }^{72}$ Moreover, actions assigned to courts were highly likely to result in a ban from the securities industry, once a violation had been established. In contrast, administrative proceedings resulted in industry bans much less often. These patterns provide an overview of the SEC's enforcement strategy at the time and can help illustrate how the agency's choices have since evolved.

\section{Violations in Administrative and Court Proceedings}

Table 1 shows the types of violations considered in administrative proceedings and courts. Violation type was a key determinant of the SEC's choice of venue, as certain violations were primarily assigned to court proceedings, while other violations were primarily assigned to administrative proceedings. More specifically, violations that may have given rise to criminal liability were assigned mostly to courts. Violations with potential criminal law implications were usually fraudbased. ${ }^{73}$ On the other hand, violations assigned mostly to administrative proceedings often related to a failure to supervise.$^{74}$ Some violations were roughly equally represented in both administrative and court proceedings. ${ }^{75}$ However, Table 1 also suggests that most violation categories generally got assigned either to administrative or to court proceedings. ${ }^{76}$ For example, the first row in Table 1 presents the sixty-five cases where violators had been acting as broker-dealers while not registered as such with the SEC, or had other problems with their registration. Of those, 18 percent (twelve cases) were assigned to administrative proceedings, and 82 percent (fifty-three cases) were assigned to courts.

This distribution of violations in administrative proceedings and courts runs contrary to a concern-expressed by some in the legal literature-that the SEC assigns sophisticated violations to administrative proceedings rather than courts

72. For a discussion of these arguments, see supra text accompanying note 65 .

73. Violations assigned mostly to courts are acting as a broker-dealer while unregistered, investor fraud, insider trading, market manipulation, misappropriating investor funds, and running a Ponzi scheme.

74. Violations assigned mostly to administrative proceedings are failure to maintain appropriate books and records, failure to supervise employees, internal control failures, and late trading.

75. These include aiding and abetting fraud, bribery, underwriter misconduct, failure to disclose material information, market timing, and unauthorized churning.

76. Violations assigned exclusively to administrative proceedings are violation of best execution duties, false net capital computation, fraud in auction-rate securities, selling unregistered stock, and violation of MSRB rules (in total, twenty-eight cases). Violations assigned exclusively to courts are conspiracy to commit securities fraud, insider trading based on firms' clients' orders, and obstruction of justice (in total, forty-six cases). 
Table 1

Distribution of Violations and Average Length of Bar (in months) by Violation in Administrative and Court Proceedings

\begin{tabular}{|c|c|c|c|c|c|c|}
\hline \multirow[b]{2}{*}{ Violation Type } & \multicolumn{3}{|c|}{ Admin. Proceedings } & \multicolumn{3}{|c|}{ Court Proceedings } \\
\hline & (\%) & Cases & $\begin{array}{l}\text { Bar in } \\
\text { months }\end{array}$ & (\%) & Cases & $\begin{array}{l}\text { Bar in } \\
\text { months }\end{array}$ \\
\hline $\begin{array}{l}\text { Acted as } \mathrm{BD} \text { while } \\
\text { unregistered }\end{array}$ & 18 & 12 & 41 & 82 & 53 & 112 \\
\hline $\begin{array}{l}\text { Aided and abetted } \\
\text { fraud }\end{array}$ & 58 & 7 & 25 & 42 & 5 & 98 \\
\hline Books and records & 88 & 29 & 5 & 12 & 4 & 60 \\
\hline Bribery & 50 & 1 & 120 & 50 & 1 & 120 \\
\hline $\begin{array}{l}\text { Conspiracy to } \\
\text { commit securities } \\
\text { fraud }\end{array}$ & - & - & - & 100 & 37 & 120 \\
\hline $\begin{array}{l}\text { Defrauded } \\
\text { investors }\end{array}$ & 23 & 16 & 73 & 77 & 53 & 110 \\
\hline $\begin{array}{l}\text { Failed best } \\
\text { execution duties }\end{array}$ & 100 & 6 & 0 & - & - & - \\
\hline $\begin{array}{l}\text { Failed to } \\
\text { disclose material, } \\
\text { information }\end{array}$ & 62 & 29 & 39 & 38 & 18 & 94 \\
\hline Failed to supervise & 95 & 41 & 15 & 5 & 2 & 72 \\
\hline $\begin{array}{l}\text { Failure as } \\
\text { underwriter }\end{array}$ & 56 & 10 & 8 & 44 & 8 & 120 \\
\hline $\begin{array}{l}\text { False net capital } \\
\text { computation }\end{array}$ & 100 & 1 & 0 & - & - & - \\
\hline $\begin{array}{l}\text { Fraudulent } \\
\text { practices in auction } \\
\text { rate securities }\end{array}$ & 100 & 14 & 0 & - & - & - \\
\hline Insider trading & 18 & 2 & 63 & 82 & 9 & 111 \\
\hline $\begin{array}{l}\text { Insider trading } \\
\text { based on firms' } \\
\text { clients' orders }\end{array}$ & - & - & - & 100 & 8 & 120 \\
\hline $\begin{array}{l}\text { Internal control } \\
\text { failure }\end{array}$ & 89 & 8 & 0 & 11 & 1 & 60 \\
\hline Late trading & 80 & 4 & 30 & 20 & 1 & 120 \\
\hline $\begin{array}{l}\text { Market } \\
\text { manipulation }\end{array}$ & 28 & 11 & 103 & 72 & 28 & 116 \\
\hline Market timing & 57 & 17 & 26 & 43 & 13 & 96 \\
\hline $\begin{array}{l}\text { Misappropriated } \\
\text { investor funds }\end{array}$ & 20 & 11 & 57 & 80 & 43 & 120 \\
\hline
\end{tabular}


Table 1 (continued)

\begin{tabular}{|c|c|c|c|c|c|c|}
\hline \multirow[b]{2}{*}{ Violation Type } & \multicolumn{3}{|c|}{ Admin. Proceedings } & \multicolumn{3}{|c|}{ Court Proceedings } \\
\hline & (\%) & Cases & $\begin{array}{l}\text { Bar in } \\
\text { months }\end{array}$ & (\%) & Cases & $\begin{array}{l}\text { Bar in } \\
\text { months }\end{array}$ \\
\hline $\begin{array}{l}\text { Obstruction of } \\
\text { justice against SEC } \\
\text { members }\end{array}$ & - & - & - & 100 & 2 & 120 \\
\hline Ponzi scheme & 7 & 1 & 120 & 93 & 13 & 120 \\
\hline $\begin{array}{l}\text { Sold unregistered } \\
\text { stock }\end{array}$ & 100 & 2 & 120 & - & - & - \\
\hline $\begin{array}{l}\text { Unauthorized } \\
\text { churning }\end{array}$ & 42 & 8 & 33 & 58 & 11 & 109 \\
\hline $\begin{array}{l}\text { Violation of } \\
\text { municipal } \\
\text { securities rules }\end{array}$ & 100 & 5 & 0 & - & - & - \\
\hline$\overline{\text { Total }}$ & & 235 & & & 310 & \\
\hline
\end{tabular}

so as to engage in "rulemaking by adjudication." 77 However, as Table 1 demonstrates, the SEC distributed evenly between courts and administrative proceedings various sophisticated violations. For example, courts reviewed approximately half of all cases concerning market timing and unauthorized churning, violations that ranked highly on the SEC's agenda during the sample period. Other highly sophisticated violations were mostly sent to courts. For example, courts reviewed all cases involving insider trading based on orders of firms' clients, which required a detailed understanding of trading systems.

Apart from violation type, the SEC may base its choice of venue on harm to investors. When such harm is severe, the SEC might prefer court proceedings because the participation of a judge offers higher safeguards of objectivity and may afford more opportunities for investor involvement. The most apparent measure of investor harm would be compensatory damages. However, damages are not awarded in SEC enforcement actions because those actions do not involve private plaintiffs. Instead, monetary remedies in SEC actions consist of either civil penalties (fines) or disgorgement orders ${ }^{78}$ Fines seek primarily to deter potential wrongdoers rather than compensate victims, ${ }^{79}$ and thus they could reflect many regulatory priorities beyond investor harm. ${ }^{80}$

77. See Harvey L. Pitt \& Karen L. Shapiro, Securities Regulation by Enforcement: A Look Ahead at the Next Decade, 7 Yale J. ON REG. 149, 156 (1990).

78. See supra notes 52-54 and accompanying text.

79. See Barbara Black, Should the SEC Be a Collection Agency for Defrauded Investors?, 63 Bus. Law. $317,323-24(2008)$

80. The character of the SEC'S civil penalties has been at the heart of Judge Rakoff's initial rejection of the proposed settlement between the SEC and Bank of America. While the 
Disgorgement orders, rooted in equitable principles of unjust enrichment, seek to recoup ill-gotten gains or losses avoided as a result of illicit activities. Thus, disgorgement orders are narrower in scope than damages, which seek to compensate investors for any harm irrespective of the violators' profits. The character of certain violations may preclude specific profits or losses avoided and, consequently, disgorgement orders: for example, false net capital computations are unlikely to result in disgorgement. In some cases, violators may have failed to gain profits or avoid losses, or such amounts may be hard to identify, thus impeding a disgorgement order. Yet, factual patterns that limit or impede the calculation of disgorgement within a certain violation type should not vary systematically between actions that have been assigned to courts or to administrative proceedings, or between actions involving bigger and smaller firms.

Although disgorgement orders are an imperfect measure of investor harm, they still present some distinct advantages. Rules for calculating disgorgement are consistent across administrative and court proceedings and across violation types, while the level of civil penalties is largely discretionary. ${ }^{81}$ Moreover, despite the conceptual differences between disgorgement and compensatory damages, in practice courts follow very similar approaches to calculate them; some commentators argue that in some securities fraud cases the "ill-gotten gains" of a defendant are merely the flip side of the damages suffered by investors. $^{82}$

The analysis in Part IV uses disgorgement orders as a proxy for the harm caused to investors, and also introduces fines as a control in certain models. Disgorgement orders were issued in 83 administrative proceedings and 138 court cases. As Table 2 demonstrates, disgorgement amounts tended to be slightly higher in court proceedings. Overall, Table 1 and Table 2 suggest that courts handled more severe violations than ALJs, since they were the venue of choice for fraud-based violations and violations that had inflicted somewhat more harm upon investors.

SEC, in its proposed settlement, sought to underscore the deterrent character of the proposed civil penalty of $\$ 33$ million, Rakoff was concerned that a civil penalty would further penalize shareholders already harmed by as much as $\$ 5.8$ billion due to management misconduct. See SEC v. Bank of Am. Corp., 653 F. Supp. 2d 507, 508-09 (S.D.N.Y. 2009). In its renegotiated settlement proposal, the SEC offered to distribute a civil penalty amounting to $\$ 150$ million to harmed shareholders. See Memorandum of Plaintiff Securities and Exchange Commission in Support of Entry of Proposed Consent Judgment, SEC v. Bank of Am. Corp., Nos. 09 Civ. 6829 (JSR), 10 Civ. 0215 (JSR), 2010 WL 624581 (S.D.N.Y. Feb. 22, 2010), 2010 WL 430123.

81. The Securities Exchange Act of 1934 contains maximum amounts of civil penalties for each action committed by securities laws violators. These maximum amounts are structured in tiers, depending on whether the action involved fraud, deceit, manipulation, or deliberate or reckless disregard of a regulatory requirement, and whether the action resulted in substantial losses or gains. See Exchange Act \& 21B(b), 15 U.S.C. \& 78u-2(b) (2006 \& Supp. IV 2010). However, because violations can be counted in many ways (e.g., each day of a disclosure violation can constitute a separate violation), the Commission and courts retain significant discretion in determining fine amounts.

82. See Elaine Buckberg \& Frederick C. Dunbar, Disgorgement: Punitive Demands and Remedial Offers, 63 Bus. Law. 347, 353 (2008). 
Table 2

Distribution of Disgorgement Awards in Administrative and Court Proceedings

\begin{tabular}{lcc}
\hline Award Amount & $\begin{array}{c}\text { Administrative } \\
\text { Proceedings } \\
(\%)\end{array}$ & $\begin{array}{c}\text { Courts } \\
(\%)\end{array}$ \\
\hline 0 & 65 & 41 \\
$1-100,000$ & 17 & 13 \\
$100,001-500,000$ & 7 & 19 \\
$500,001-1,000,000$ & 3 & 5 \\
$1,000,001-3,000,000$ & 1 & 10 \\
$3,000,001$ and above & 7 & 12 \\
\hline
\end{tabular}

\section{Settlement in Administrative and Court Proceedings}

Defendants settled with the SEC in 90 percent of all cases in the dataset assigned to administrative proceedings; of the 235 cases assigned to administrative proceedings, only twenty-four reached a hearing before the ALJ, and in five of those hearings, defendants were in default. In 199 cases ( 85 percent), the settlement was pre-negotiated with the SEC, which issued a single release announcing the initiation and the conclusion of the enforcement action, along with the terms of the settlement. In courts, defendants settled in 74 percent of the cases in the dataset, were in default in 4 percent of cases, and litigated the case fully in 12 percent of cases. ${ }^{83}$

Calculating how quickly defendants settled in each venue is impossible because the SEC does not release information about when it opened settlement negotiations, launched an investigation, or became aware of the defendants' misconduct. However, the SEC provides information about the date on which each violation occurred, or the period in which defendants engaged in multiple or continuous violations. These dates could offer some indication-clearly imperfect-of the duration of efforts to resolve the cases and the impact of settlement negotiations. On average, administrative proceedings led to resolution of the case 2.9 years after the completion of any violations, while court proceedings led to resolution 3.3 years after their completion. The 0.4 years differential between the two venues seems small, and it could be due to speedier resolution in the administrative

83. In the remaining 10 percent of cases, it was not possible to tell, based on the Commission's litigation releases, whether the defendants had settled. 
venue, to complications arising from the character of violations predominantly assigned to courts, or to the SEC directing to administrative proceedings defendants more willing to settle.

\section{Penalties in Administrative and Court Proceedings}

An order that bans a defendant from the broker-dealer industry is a major sanction because it taints a defendant's reputation and typically results in terminating the person's career. Table 3 presents the distribution of bars and suspensions in court and administrative proceedings. It highlights a key finding of the article: following court injunctions against defendants, the SEC almost always exercised its discretion and prohibited defendants from continuing their professional activity as broker-dealers, considering a permanent bar to be in the public interest. Provided that there had been a violation of the securities laws, 90 percent of all cases that went to court resulted in a permanent ban from the broker-dealer industry. In contrast, only 20 percent of administrative cases resulted in a permanent ban, while more than half of those cases resulted in very low administrative sanctions. Table 1 compares the average bar's length (in months) ordered in administrative proceedings and courts for the same type of violation. It shows that, on average, industry bans following a court injunction were at least as lengthy, and in most cases lengthier, than industry bans imposed in administrative proceedings for the same violation.

On the other hand, Table 4 shows that civil penalties were slightly higher in SEC administrative proceedings, although they remained below $\$ 100,000$ in 70 percent of administrative proceedings and 84 percent of court proceedings.

Table 3

Industry Bars in Administrative Proceedings and Courts

\begin{tabular}{lccccc}
\hline \multirow{2}{*}{ Bar or } & \multicolumn{2}{c}{ Administrative Proceedings } & & \multicolumn{2}{c}{ Courts } \\
\cline { 2 - 3 } \cline { 6 - 6 } Suspension & Cases & $(\%)$ & & Cases & $(\%)$ \\
\hline No bar & 121 & 51 & & 4 & 1 \\
Bar $<6$ months & 19 & 8 & & 2 & 1 \\
6 months $<$ bar $<1$ year & 25 & 11 & & 3 & 1 \\
l year $<$ bar $<2$ years & 7 & 3 & & 5 & 2 \\
2 years $<$ bar $<5$ years & 15 & 6 & & 17 & 5 \\
Permanent bar & 48 & 20 & & 279 & 90 \\
\hline Total & 235 & 100 & 310 & 100 \\
\hline
\end{tabular}


Table 4

Distribution of Fines in Administrative Proceedings and Courts

\begin{tabular}{lcc}
\hline Fine Amount & $\begin{array}{c}\text { Administrative } \\
\text { Proceedings } \\
(\%)\end{array}$ & $\begin{array}{c}\text { Courts } \\
(\%)\end{array}$ \\
\hline 0 & 23 & 62 \\
$1-100,000$ & 44 & 22 \\
$100,001-500,000$ & 18 & 9 \\
$500,001-1,000,000$ & 3 & 1 \\
$1,000,001-3,000,000$ & 5 & 3 \\
$3,000,001$ and above & 7 & 3 \\
\hline
\end{tabular}

\section{Corporate Liability, Assignment to Court, and Sanctions: MaIN Findings}

This Part addresses three key choices the SEC faces in shaping an enforcement action. First, this Part explores whether the main targets of SEC actions are individual wrongdoers, the broker-dealer firms that employ them, or both, and whether the SEC's choice of defendant is different for big and small firms. Second, this Part considers whether big firms, and the employees associated with big firms, are more likely to be assigned to court or administrative proceedings. Third, having thus explored the composition of the two defendant pools, this Part focuses exclusively on administrative defendants. It examines whether the SEC is likely to impose lower sanctions, i.e., shorter industry bars and lower fines, on big firms and their employees in comparison to small firms and their employees.

Because the hypotheses explored below focus on registered broker-dealers, the analysis excludes fifty-two cases in which violators had not been registered with the SEC in any capacity at the time of violation. Thus, small "fly-by-night" operations that often engage in rapacious fraud are not part of the main analysis. The analysis in Part IV also excludes cases in which the violator's employer could not be identified, i.e., twenty-three cases where the violator's employer is not disclosed and twenty-two cases where violators had multiple employers during their misconduct. In total, the sample in Part IV includes 448 cases.

\section{A. Individual and Corporate Liability for Different Violation TYPES}

This study shows that, when big firms were involved in some misconduct, the SEC relied heavily on corporate liability. When SEC actions targeted a big financial firm for securities laws violations, they often avoided identifying any specific individuals within the firm as a violator; neither front-line employees who participated in misconduct nor high-level supervisors were subject to any addi- 
tional action. Typically, these actions resulted in fines, often very high ones, paid by the firm and agreed to in settlements between the SEC and big firms. In administrative proceedings, these settlements almost always occurred concurrently with the initiation of the action. While violation types and lack of adequate evidence may explain some firm-only actions, they do not fully account for the extensive use of these actions by the SEC, as the paragraphs below explain.

As Tables $5 \mathrm{a}$ and $5 \mathrm{~b}$ demonstrate, 40 percent of all enforcement actions against big firms targeted the firm alone without placing any liability on particular individuals, compared to just 10 percent of all small-firm actions. Particularly in administrative proceedings, more than half of all big-firm actions involved only corporate liability. Almost all firm-only actions against big firms occurred in administrative proceedings. ${ }^{84}$

Firm-only actions are, on average, of a higher profile compared to other cases in the SEC's enforcement record, as the data below shows. The average fine against a big firm in a firm-only action was $\$ 11.9$ million, compared to just $\$ 2.3$ million in actions that involved both corporate and individual liability. ${ }^{85}$ The dataset includes eight SEC actions that resulted in a fine higher than $\$ 10$ million, and they all concerned exclusive corporate liability. Although almost all firm-only actions resulted in fines, only about 20 percent of those cases included a disgorgement award. Where included, disgorgement awards in firm-only actions were substan-

Table 5a

Actions Targeting Firms and Individuals in Courts and Administrative Proceedings

\begin{tabular}{lccc}
\hline & $\begin{array}{c}\text { Firms Only } \\
\text { Cases (\%) }\end{array}$ & $\begin{array}{c}\text { Firms \& Individuals } \\
\text { Cases (\%) }\end{array}$ & $\begin{array}{c}\text { Individuals Only } \\
\text { Cases (\%) }\end{array}$ \\
\hline Small & $34(10)$ & $91(26)$ & $220(64)$ \\
Big & $41(40)$ & $21(20)$ & $41(40)$ \\
\hline
\end{tabular}

Table $5 b$

Actions Targeting Firms and Individuals in Administrative Proceedings Only

\begin{tabular}{lccc}
\hline & $\begin{array}{c}\text { Firms Only } \\
\text { Cases (\%) }\end{array}$ & $\begin{array}{c}\text { Firms \& Individuals } \\
\text { Cases (\%) }\end{array}$ & $\begin{array}{c}\text { Individuals Only } \\
\text { Cases (\%) }\end{array}$ \\
\hline Small & $33(23)$ & $64(45)$ & $44(31)$ \\
Big & $40(55)$ & $19(26)$ & $14(14)$ \\
\hline
\end{tabular}

84. The strong presence of big firms in firm-only actions is confirmed by regression analysis, not reported here, including controls for types of violations, levels of disgorgement, and year.

85. Small firms also got higher fines in firm-only actions. In those actions, the average fine for a small firm was $\$ 3.8$ million, compared to $\$ 0.5$ million in actions that also implicate individuals. 
tially higher, on average, than disgorgement awards against firms in cases that also involved individual liability.

With regard to violations for which individuals were the exclusive targets of SEC actions, the data generally confirms expectations based on the analysis of the legal framework. As Table 6 shows, the SEC preferred to charge only individuals for violations that involved textbook cases of fraud, and that were often particularly egregious, such as misappropriation of investor funds or general investor fraud; those violations resulted in individual-only actions even when committed by big-firm employees. Fraud violations are the key target of modern compliance systems, which typically incorporate steps deemed necessary to avert such conduct, allowing broker-dealer firms to establish successfully the good-faith defense. ${ }^{86}$ Moreover, the charges against specific individuals for such violations are in line with the firm's interests, as they frame the targeted individuals as "bad apples" and distinguish them from the firm as a whole, which can thus clear its reputation. Finally, all SEC actions for insider trading or front running involve individuals, since those violations establish a higher liability threshold for firms. ${ }^{87}$

Table 6

Actions Against Firms and Individuals by Violation Type

\begin{tabular}{lcccc}
\hline & \multicolumn{4}{c}{ Firms \& Individuals } \\
\cline { 2 - 5 } Violation Type & Firms Only & Firms & Individuals & Individuals \\
Only
\end{tabular}

\footnotetext{
86. The law requires broker-dealer firms to establish procedures and systems that would reasonably be expected to prevent and detect violations of the securities laws. See Securities Exchange Act of 1934 \$ $15(b)(4)(E), 15$ U.S.C. \& $780(b)(4)$ (E) (2006 \& Supp. IV 2010). If a firm's compliance arrangements fulfill the reasonableness standard, then it can validly claim that it has discharged its supervisory obligations. For a more detailed discussion on failures to supervise, see Part V below. More generally, the Exchange Act provides that controlling persons who acted in good faith are not liable for a controlled person's violations. Exchange Act \& 20(a), 15 U.S.C. \& 78t(a) (2006 \& Supp. IV 2010).

87. The Commission can seek civil penalties in district court against a controlling person for insider trading only if it establishes that the controlling person recklessly disregarded the possibility of insidertrading by controlled persons, or recklessly failed to establish any supervisory process. Exchange Act \$ 21 A, 15 U.S.C. \& 78u-l(b)(1) (2006 \& Supp. IV 2010). For a discussion, see Steve Thel, Statutory Findings and Insider Trading Regulation, 50 VAND. L. REv. 1091 (1997).
} 
Table 6 (continued)

\begin{tabular}{|c|c|c|c|c|}
\hline \multirow[b]{2}{*}{ Violation Type } & \multicolumn{4}{|c|}{ Firms \& Individuals } \\
\hline & Firms Only & Firms & Individuals & $\begin{array}{l}\text { Individuals } \\
\text { Only }\end{array}$ \\
\hline Failed to disclose material information & 7 & 8 & 9 & 23 \\
\hline Failed to supervise & 4 & 10 & 11 & 18 \\
\hline Failure as underwriter & 1 & 4 & 5 & 8 \\
\hline False net capital computation & 0 & 0 & 0 & 1 \\
\hline $\begin{array}{l}\text { Fraudulent practices in auction rate } \\
\text { securities }\end{array}$ & 14 & 0 & 0 & 0 \\
\hline Insider trading & 0 & 0 & 1 & 10 \\
\hline $\begin{array}{l}\text { Insider trading based on firms' clients' } \\
\text { orders }\end{array}$ & 0 & 0 & 0 & 8 \\
\hline Internal control failure & 2 & 3 & 4 & 0 \\
\hline Late trading & 3 & 0 & 0 & 2 \\
\hline Market manipulation & 1 & 2 & 2 & 34 \\
\hline Market timing & 7 & 4 & 7 & 12 \\
\hline Misappropriated investor funds & 0 & 6 & 10 & 38 \\
\hline $\begin{array}{l}\text { Obstruction of justice against SEC } \\
\text { members }\end{array}$ & 0 & 0 & 0 & 2 \\
\hline Ponzi scheme & 0 & 1 & 1 & 12 \\
\hline Sold unregistered stock & 0 & 0 & 2 & 0 \\
\hline Unauthorized churning & 1 & 1 & 3 & 14 \\
\hline Violation of municipal securities rules & 1 & 1 & 3 & 0 \\
\hline Total & 75 & 46 & 66 & 358 \\
\hline
\end{tabular}

While violation types help explain why the SEC sometimes decided to charge individuals alone, they cannot fully explain why in some cases the SEC charged both an employee and her firm, while in other cases it charged the firm only. Table 7 presents the types of violations for which the SEC did not charge any individuals, depending on whether the targeted firm was big or small. Arguably, the nature of some violations might prevent regulators from pinpointing individual actors as culpable. While in theory every violation is the consequence of some individual's actions, responsibility for certain violations may be more diffuse within a firm, particularly when the law places a specific obligation on the firm as a whole. Or, not all elements of a violation might be in place for a specific individual. For example, books and records violations might have been the result of firm practices developed over various years by multiple firm officials. Most of 
Table 7

Firm-Only Actions By Small and Big Firms

\begin{tabular}{lccc}
\hline Violation & Small & Big & Total \\
\hline Acted as BD while unregistered & 0 & 2 & 2 \\
Books and records & 20 & 6 & 26 \\
Failed best execution duties & 2 & 4 & 6 \\
Failed to disclose material information & 4 & 3 & 7 \\
Failed to supervise & 1 & 3 & 4 \\
Failure as underwriter & 0 & 1 & 1 \\
Auction rate securities fraud & 1 & 13 & 14 \\
Internal control failure & 0 & 2 & 2 \\
Late trading & 1 & 2 & 3 \\
Market manipulation & 0 & 1 & 1 \\
Market timing & 3 & 4 & 7 \\
Unauthorized churning & 1 & 0 & 1 \\
Violation of MSRB rules & 1 & 0 & 1 \\
\hline Total & 34 & 41 & 75 \\
\hline
\end{tabular}

the books and records actions against small firms occurred in 1998 and involved deficiencies in their preparation for potential Year 2000 disruptions.

Still, arguments about diffuse liability within firms cannot justify firm-only actions when the fact patterns in question were very similar to fact patterns in cases brought against individuals. For example, market timing and late trading cases involve trades in mutual funds during a very specific time window around the calculation of the funds' net asset value. The SEC brought various actions for market timing and late trading against individuals. ${ }^{88}$ Similarly, most cases of failure to disclose material information involve revenue sharing agreements or other premiums that brokerage firms received for promoting certain mutual fund families but kept secret from their mutual fund investors. The Commission brought cases against some individuals for not disclosing to clients conflicts of interests, even when those conflicts arose from their employers' position and not their own, but did not charge others who appear, from the public record, to have been similarly situated. ${ }^{89}$

88. See, e.g., In re Powell, Release No. 34-51017, 84 SEC Docket 2346, 2005 WL 53296 (Jan. 11, 2005); In re Addeo, Release No. 34-51589, 85 SEC Docket 734, 2005 WL 924279 (Apr. 21, 2005); In re Laughlin, Release No. 34-51624, 85 SEC Docket 914, 2005 WL 990561 (Apr. 28, 2005); In re Braun, Release No. 34-51914, 85 SEC Docket 2217, 2005 WL 1498422 (June 23, 2005).

89. See, for example, In re Silva, Release No. 34-52617, 86 SEC Docket 1210, 2005 WL 2673496 (Oct. 17, 2005), where the SEC brought an action against the chairman of a firm for failing to disclose the side payments the firm received to promote certain stocks, and In re Prudential Equity Group, LLC, Release No. 34-52116, 85 SEC Docket 3278, 2005 WL 1963699 (July 25, 2005), where the SEC issued a cease-and-desist order against a brokerage firm for not disclosing that it had received payments in return for publishing research for certain public companies. 
Evidence collection problems might explain the SEC's choice to bring an action only against the firm as a whole in cases involving big firms, while opting for individual actions in small-firm cases. With regard to many small firms, the SEC can easily secure evidence against the few front-line employees who might have been involved in misconduct. Because big firms have more complicated operations, regulators may face greater challenges in identifying specific violators. However, the SEC administrative orders in firm-only actions did not indicate severe diffculties in collecting information about individual violators. In many such orders, the language suggested that an individual was easily identifiable, if not identified already. Thus, concerns regarding evidence collection and proper attribution of misconduct do not seem to be the key driver behind the SEC's decision to pursue an action exclusively against a firm, although a thorough look at the SEC's evidence would be necessary before excluding that possibility.

Although it is not clear that broker-dealer firm preferences drive these results, broker-dealer firms may prefer to avoid charges against specific individuals for various reasons. Firms may worry that revelations about specific actions might expose their weaknesses and increase negative reports in the news. Moreover, conflicts of interests within firms could explain these choices. In some cases, the firm's representatives in negotiations with the SEC might be more sympathetic to the targeted employees than to anonymous shareholders; in other cases, targeted individuals may rank high in the firm's hierarchy, and firm representatives may seek their support.

Corporate liability helps deflect sanctions away from managers and employees ${ }^{90}$ because it provides judges, juries, and regulators with the opportunity to castigate misconduct "without sending a real human to jail." ditional incentives to favor corporate fines in cases in which a misconduct pattern is widespread within the financial industry, such as the mutual fund scandals in 2003-2004. By pointing to other firms' corporate fines, managers can signal to boards and shareholders that overlooking a fraudulent pattern was not a personal failure, but an industry-wide deficiency.

\section{B. Likelihood of Court Proceedings}

Among the 448 enforcement actions in the sample, 59 percent of cases against small firms or their employees ended up in court, compared to 29 percent of bigfirm cases. Since sending a firm to court might have significant negative consequences, including the closing down of the business from the associated negative press coverage, the SEC might be more reluctant to bring lawsuits against firms, particularly big ones. Indeed, when examining enforcement actions against corporate entities, the likelihood of going to court was just 2 percent for a big firm and 16 percent for a small firm. More surprisingly, however, the SEC seemed less

90. See Vikramaditya S. Khanna, Corporate Crime Legislation: A Political Economy Analysis, 82 WaSH. U. L.Q. 95, 117-19 (2004). For a discussion of how CEOs and companies bargain about trading, see generally M. Todd Henderson, Insider Trading and CEO Pay, 64 VAND. L. REV. 505 (2011).

91. Khanna, supra note 90 , at 118. 
willing to send to courts individuals associated with big firms, compared to their small-firm counterparts: the likelihood of going to court was 53 percent for bigfirm employees, compared to 71 percent for small-firm employees.

The analysis below uses logistic regression models to predict forum selection, i.e., whether cases concerning big and small firms are likely to be assigned to administrative or court proceedings, taking into account the type of violation and the harm caused to investors. The dependent variable takes a value of " 0 " if the case is assigned to administrative proceedings, and a value of " 1 " if the case is handled by a court. ${ }^{92}$

Since the SEC has full discretion to direct an enforcement action against specific individuals, the firm associated with those individuals, or both, pooling observations for firms and individuals is appropriate for many analytical purposes. The SEC's flexibility allows regulated entities to negotiate the defendant choice as part of their settlement, particularly where the SEC initiates the action formally only after agreeing on settlement terms, either by instituting administrative proceedings or, less often, by filing settled charges in court. ${ }^{93}$ The discussion below contains both results based on pooled data, and results based on separate analysis of firm and individual data. There are no substantial differences.

Model I includes controls for the type of violation, while Model II introduces the logarithm of disgorgement amounts as an additional control. ${ }^{94}$ These regressions do not use the level of fines as a proxy for harm to investors because the level of fines in courts and administrative proceedings may be subject to different considerations in light of the need to obtain court approval. Both models also include a dummy variable for corporate and individual defendants, since firms are less likely than individuals to end up in court. Yet, cases that implicate both firms and individuals in the same fact pattern may result in different treatment for individual violators, since corporate liability may add another source of compensation for investors. To account for this potential effect, these models also include a dummy for such cases. Year dummies are also included to account for any yearspecific effects (e.g., a new type of violation being identified and rigorously pursued in a given year), or any changes in the SEC's chairmanship. Standard errors are clustered by SEC release, since unobserved common factors might be driving both a finding of violation against one of the targeted individuals or firms in a case and the remaining persons involved in the same factual pattern.

92. As already mentioned, the sample excludes fifty-two cases in which the defendants acted as broker-dealers without being registered with the SEC or without being associated with a firm registered with the SEC in any capacity, twenty-three cases in which the defendants' employer was not disclosed, and twenty-two cases in which the defendants were associated with multiple employers during the period in which they engaged in misconduct.

93. See Richard M. Phillips \& Brian A. Ochs, Settlements: Minimizing the Adverse Effects of an SEC Enforcement Action, in The Securities Enforcement Manual 257, 260 (Michael J. Missal \& Richard M. Phillips eds., 2007). The SEC does not overtly accept that these negotiating options are open to defendants.

94. The logarithm takes a value of " 0 " in cases in which the court or the SEC has not ordered the payment of disgorgement. When limiting the analysis to the 200 cases in which disgorgement was ordered, results remain in the same direction but are not statistically significant in all models, due to the reduction in sample size. 
Because cases involving criminal liability always end up in court, Model III repeats the analysis for a subset of the sample that excludes cases where criminal charges were also brought. Finally, since corporate employers are also less likely to end up in court, Model IV further limits the sample to individuals subject to civil liability.

Table 8

Models Predicting Assignment of Big and Small Firms to Administrative and Court Proceedings

\begin{tabular}{|c|c|c|c|c|}
\hline & Model I & Model II & Model III & Model IV \\
\hline & $\begin{array}{l}\text { Odds Ratio } \\
\text { (std. error) }\end{array}$ & $\begin{array}{l}\text { Odds Ratio } \\
\text { (std. error) }\end{array}$ & $\begin{array}{l}\text { Odds Ratio } \\
\text { (std. error) }\end{array}$ & $\begin{array}{l}\text { Odds Ratio } \\
\text { (std. error) }\end{array}$ \\
\hline Big firm & $\begin{array}{l}0.35^{* *} \\
(0.14)\end{array}$ & $\begin{array}{l}0.29^{* * *} \\
(0.13)\end{array}$ & $\begin{array}{l}0.25^{* * *} \\
(0.12)\end{array}$ & $\begin{array}{l}0.25^{* *} \\
(0.17)\end{array}$ \\
\hline Firm/Individual & $\begin{array}{l}0.11^{* * *} \\
(0.04)\end{array}$ & $\begin{array}{l}0.07^{* * *} \\
(0.04)\end{array}$ & $\begin{array}{l}0.06^{* * *} \\
(0.04)\end{array}$ & - \\
\hline $\begin{array}{l}\text { Defendant in proceedings for firm } \\
\text { and individual liability }\end{array}$ & $\begin{array}{l}0.35^{* *} \\
(0.17)\end{array}$ & $\begin{array}{c}0.46 \\
(0.26)\end{array}$ & $\begin{array}{c}0.90 \\
(0.59)\end{array}$ & $\begin{array}{c}0.54 \\
(0.35)\end{array}$ \\
\hline Level of disgorgement & 一 & $\begin{array}{l}1.08^{* * *} \\
(0.03)\end{array}$ & $\begin{array}{l}1.16^{* * *} \\
(0.04)\end{array}$ & $\begin{array}{l}1.16^{* * *} \\
(0.05)\end{array}$ \\
\hline $\begin{array}{l}\text { Acted as BD while unregistered; } \\
\text { defrauded investors }\end{array}$ & $\begin{array}{l}15.96^{* *} \\
(19.28)\end{array}$ & $\begin{array}{c}6.35 \\
(8.01)\end{array}$ & $\begin{array}{c}1.33 \\
(2.25)\end{array}$ & $\begin{array}{c}3.13 \\
(4.68)\end{array}$ \\
\hline Aided and abetted fraud & $\begin{array}{c}0.90 \\
(1.08)\end{array}$ & $\begin{array}{c}0.55 \\
(0.63)\end{array}$ & $\begin{array}{c}0.22 \\
(0.32)\end{array}$ & $\begin{array}{c}0.42 \\
(0.54)\end{array}$ \\
\hline Books and records & $\begin{array}{l}1.68 \\
(2.13)\end{array}$ & $\begin{array}{c}2.11 \\
(2.84)\end{array}$ & $\begin{array}{l}1.40 \\
(2.61)\end{array}$ & $\begin{array}{l}3.96 \\
(7.76)\end{array}$ \\
\hline Bribery & $\begin{array}{c}1.91 \\
(4.61)\end{array}$ & $\begin{array}{c}1.48 \\
(4.69)\end{array}$ & - & - \\
\hline Conspiracy to commit securities fraud & - & - & - & - \\
\hline Defrauded investors & $\begin{array}{l}8.44^{* *} \\
(8.60)\end{array}$ & $\begin{array}{c}2.48 \\
(2.50)\end{array}$ & $\begin{array}{c}0.47 \\
(0.68)\end{array}$ & $\begin{array}{l}1.36 \\
(1.57)\end{array}$ \\
\hline Failed best execution duties & - & - & - & - \\
\hline $\begin{array}{l}\text { Failed to disclose material } \\
\text { information }\end{array}$ & $\begin{array}{l}1.89 \\
(1.94)\end{array}$ & $\begin{array}{c}0.89 \\
(0.93)\end{array}$ & $\begin{array}{c}0.25 \\
(0.35)\end{array}$ & $\begin{array}{c}0.41 \\
(0.49)\end{array}$ \\
\hline Failed to supervise & $\begin{array}{c}0.08^{*} \\
(0.10)\end{array}$ & $\begin{array}{l}0.04^{* *} \\
(0.06)\end{array}$ & $\begin{array}{c}0.02^{* *} \\
(0.03)\end{array}$ & $\begin{array}{c}0.03^{*} \\
(0.06)\end{array}$ \\
\hline
\end{tabular}


708 The Business Lawyer; Vol. 67, May 2012

Table 8 (continued)

\begin{tabular}{|c|c|c|c|c|}
\hline & Model I & Model II & Model III & Model IV \\
\hline & \multicolumn{3}{|c|}{$\begin{array}{l}\text { Odds Ratio Odds Ratio Odds Ratio } \\
\text { (std. error) (std. error) (std. error) }\end{array}$} & $\begin{array}{l}\text { Odds Ratio } \\
\text { (std. error) }\end{array}$ \\
\hline Failure as underwriter & $\begin{array}{l}6.67 \\
(8.92)\end{array}$ & $\begin{array}{c}3.06 \\
(4.70)\end{array}$ & $\begin{array}{c}0.80 \\
(1.48)\end{array}$ & $\begin{array}{l}1.50 \\
(2.19)\end{array}$ \\
\hline False net capital computation & - & - & - & - \\
\hline $\begin{array}{l}\text { Fraudulent practices in auction rate } \\
\text { securities }\end{array}$ & - & - & - & - \\
\hline Insider trading & $\begin{array}{c}4.20 \\
(5.60)\end{array}$ & $\begin{array}{c}2.00 \\
(2.64)\end{array}$ & $\begin{array}{c}0.47 \\
(0.75)\end{array}$ & - \\
\hline $\begin{array}{l}\text { Insider trading based on firms' } \\
\text { clients' orders }\end{array}$ & - & - & - & - \\
\hline Internal control failure & $\begin{array}{c}1.23 \\
(2.17)\end{array}$ & $\begin{array}{c}0.91 \\
(1.74)\end{array}$ & - & - \\
\hline Late trading & - & - & - & - \\
\hline Market manipulation & $\begin{array}{c}5.64 \\
(5.94)\end{array}$ & $\begin{array}{c}3.61 \\
(3.83)\end{array}$ & $\begin{array}{c}0.20 \\
(0.29)\end{array}$ & $\begin{array}{c}0.43 \\
(0.50)\end{array}$ \\
\hline Market timing & $\begin{array}{c}2.02 \\
(2.09)\end{array}$ & $\begin{array}{c}0.84 \\
(0.88)\end{array}$ & $\begin{array}{c}0.19 \\
(0.29)\end{array}$ & $\begin{array}{c}0.82 \\
(1.24)\end{array}$ \\
\hline Misappropriated investor funds & $\begin{array}{l}21.85^{* * *} \\
(23.80)\end{array}$ & $\begin{array}{r}8.14^{*} \\
(8.96)\end{array}$ & $\begin{array}{c}0.51 \\
(0.84)\end{array}$ & $\begin{array}{c}0.83 \\
(1.17)\end{array}$ \\
\hline $\begin{array}{l}\text { Obstruction of justice against SEC } \\
\text { members }\end{array}$ & - & - & - & - \\
\hline Ponzi scheme & $\begin{array}{l}16.29 * \\
(25.07)\end{array}$ & $\begin{array}{c}3.05 \\
(4.41)\end{array}$ & - & $\begin{array}{c}2.10 \\
(3.36)\end{array}$ \\
\hline Sold unregistered stock & - & - & - & - \\
\hline Unauthorized churning & $\begin{array}{c}1.59 \\
(1.69)\end{array}$ & $\begin{array}{c}0.66 \\
(0.74)\end{array}$ & $\begin{array}{c}0.18 \\
(0.26)\end{array}$ & $\begin{array}{c}0.46 \\
(0.61)\end{array}$ \\
\hline Violation of MSRB rules & - & - & - & - \\
\hline Year dummies & Yes & Yes & Yes & Yes \\
\hline $\mathrm{N}$ & 382 & 333 & 263 & 178 \\
\hline
\end{tabular}

*** significant at the 0.01 level, ** significant at the 0.05 level, * significant at the 0.10 level

These regressions indicate that, after controlling for violation type, disgorgement amount, and all of the other factors mentioned above, cases involving big firms and their employees are more likely to end up in administrative proceedings, while cases involving small firms and their employees are more likely to end up in court. More specifically, according to Model IV, when all other values are 
held at their mean, the probability that a small-firm employee will go to court is 44 percent, while the probability that a big-firm employee will go to court is 18 percent. ${ }^{95}$ In other words, for the average violation and level of disgorgement, a big-firm employee is less than half as likely to end up in court than a small-firm employee.

\section{INDUSTRY Bans}

This Part explores whether the SEC is likely to impose shorter industry bans and lower fines on big-firm defendants compared to small-firm defendants. For purposes of this analysis, the sample consists exclusively of administrative proceedings that involve defendants previously registered with the SEC as brokerdealers (214 cases). Big-firm defendants are more likely to receive no industry ban or registration revocation: 73 percent of them received only a censure or cease-and-desist order, compared with 45 percent of small-firm defendants. At the other end of the spectrum, more than one quarter of small-firm defendants were permanently banned from the broker-dealer industry, compared to just 4 percent of big-firm defendants.

Table 9 presents the results of linear regression analysis predicting the length of the industry ban ordered for big- and small-firm defendants. The dependent variable in these models consists of the length of the industry ban in months. To transform a permanent ban into months, the analysis assumes a duration twice as long as the duration of the next largest ban (five years). Thus, permanent bans are treated as ten-year bans.

Model I accounts for the level of harm caused by each defendant by including the logarithm of disgorgement awards as a control, and Model II introduces controls about the type of violation in each action. However, arguably the SEC might agree to impose shorter industry bans in exchange for higher fines. To account for this possibility, Model III introduces the logarithm of fines imposed by the Commission as a control in predicting the severity of the industry ban. The sample for Models I, II, and III includes cases brought either against firms or against individuals, while Model IV limits the analysis to individuals. All four models include controls for cases where firm and individual liability arose in the same fact pattern. In all models, results are clustered by SEC release and year dummies are included.

All models confirm that industry bans for big-firm defendants were likely to be disproportionately less severe in comparison to small-firm cases. Moreover, even when limiting the analysis to cases against individuals, excluding the firms themselves, big-firm employees were likely to receive less severe bans than small-firm employees, as Model IV shows. More specifically, big-firm employees were likely to receive an industry ban almost two years (twenty-two months) shorter than a ban ordered against a small-firm employee, for the same violation, disgorgement,

95. Results are based on simulations, using CLARIFY software. See generally Gary King, Michael Tomz \& Jason Wittenberg, Making the Most of Statistical Analyses: Improving Interpretation and Presentation, 44 AM. J. POL. SCl. 347, 360 (2000) (describing the method used in this software). 
710 The Business Lawyer; Vol. 67, May 2012

Table 9

Models Predicting Length of Industry Bars for Big and Small Firm Defendants in Administrative Proceedings

\begin{tabular}{|c|c|c|c|c|}
\hline & Model I & Model II & Model III & Model IV \\
\hline & $\begin{array}{l}\text { Coefficient } \\
\text { (std. error) }\end{array}$ & $\begin{array}{l}\text { Coefficient } \\
\text { (std. error) }\end{array}$ & $\begin{array}{l}\text { Coefficient } \\
\text { (std. error) }\end{array}$ & $\begin{array}{l}\text { Coefficient } \\
\text { (std. error) }\end{array}$ \\
\hline Big firm & $\begin{array}{l}-26.08^{* * *} \\
(7.15)\end{array}$ & $\begin{array}{l}-19.70 * * * \\
(6.93)\end{array}$ & $\begin{array}{l}-14.05^{* *} \\
(6.90)\end{array}$ & $\begin{array}{l}-22.01^{*} \\
(11.74)\end{array}$ \\
\hline Firm/Individual & $\begin{array}{l}-32.00^{* * *} \\
(7.74)\end{array}$ & $\begin{array}{l}-19.09^{* *} \\
(7.75)\end{array}$ & $\begin{array}{l}-15.78^{* *} \\
(7.66)\end{array}$ & - \\
\hline Related proceedings & $\begin{array}{r}-11.37 \\
(8.41)\end{array}$ & $\begin{array}{r}-13.39^{*} \\
(7.44)\end{array}$ & $\begin{array}{l}-14.74^{* *} \\
\quad(7.22)\end{array}$ & $\begin{array}{c}-23.14^{* *} \\
(8.88)\end{array}$ \\
\hline Level of disgorgement & $\begin{array}{l}1.30^{* *} \\
(0.51)\end{array}$ & $\begin{array}{l}0.15 \\
(0.70)\end{array}$ & $\begin{array}{c}0.32 \\
(0.70)\end{array}$ & $\begin{array}{c}0.99 \\
(1.19)\end{array}$ \\
\hline Level of fines & & - & $\begin{array}{l}-2.48 * * * \\
(0.78)\end{array}$ & $\begin{array}{l}-3.27^{* * *} \\
(1.09)\end{array}$ \\
\hline $\begin{array}{l}\text { Acted as BD while } \\
\text { unregistered }\end{array}$ & & $\begin{array}{c}2.95 \\
(15.48)\end{array}$ & $\begin{array}{l}-4.27 \\
(15.89)\end{array}$ & $\begin{array}{r}-57.72^{*} \\
(30.61)\end{array}$ \\
\hline Aided and abetted fraud & & $\begin{array}{c}9.14 \\
(18.18)\end{array}$ & $\begin{array}{l}-1.51 \\
(16.67)\end{array}$ & $\begin{array}{l}-1.29 \\
(17.74)\end{array}$ \\
\hline Books and records & & $\begin{array}{l}-5.50 \\
(10.30)\end{array}$ & $\begin{array}{l}-8.61 \\
(10.45)\end{array}$ & $\begin{array}{c}36.13 \\
(47.20)\end{array}$ \\
\hline Bribery & & $\begin{array}{l}107.68^{* * *} \\
(12.23)\end{array}$ & $\begin{array}{l}111.43^{* * *} \\
(11.81)\end{array}$ & $\begin{array}{l}113.98^{* * *} \\
(18.73)\end{array}$ \\
\hline $\begin{array}{l}\text { Conspiracy to commit } \\
\text { securities fraud }\end{array}$ & & - & - & - \\
\hline Defrauded investors & & $\begin{array}{l}55.19 * * * \\
(19.25)\end{array}$ & $\begin{array}{l}39.21^{* *} \\
(17.36)\end{array}$ & $\begin{array}{c}36.32 * \\
(20.87)\end{array}$ \\
\hline Failed best execution duties & & $\begin{array}{l}-1.77 \\
(9.43)\end{array}$ & $\begin{array}{l}-3.84 \\
(11.73)\end{array}$ & - \\
\hline $\begin{array}{l}\text { Failed to disclose material } \\
\text { information }\end{array}$ & & $\begin{array}{l}31.49 * * \\
(14.70)\end{array}$ & $\begin{array}{l}26.26^{*} \\
(15.06)\end{array}$ & $\begin{array}{l}35.97^{* *} \\
(16.64)\end{array}$ \\
\hline Failed to supervise & & - & - & - \\
\hline Failure as underwriter & & $\begin{array}{l}-3.10 \\
(8.07)\end{array}$ & $\begin{array}{l}-0.72 \\
(8.06)\end{array}$ & $\begin{array}{c}5.51 \\
(15.56)\end{array}$ \\
\hline $\begin{array}{l}\text { False net capital } \\
\text { computation }\end{array}$ & & $\begin{array}{l}-33.05 \\
(20.50)\end{array}$ & $\begin{array}{l}-54.74 * * * \\
(20.68)\end{array}$ & $\begin{array}{l}-80.86^{* * *} \\
(28.26) \\
\quad \text { (continued }\end{array}$ \\
\hline
\end{tabular}


Table 9 (continued)

\begin{tabular}{|c|c|c|c|c|}
\hline & Model I & Model II & Model III & Model IV \\
\hline & $\begin{array}{l}\text { Coefficient } \\
\text { (std. error) }\end{array}$ & $\begin{array}{l}\text { Coefficient } \\
\text { (std. error) }\end{array}$ & $\begin{array}{l}\text { Coefficient } \\
\text { (std. error) }\end{array}$ & $\begin{array}{l}\text { Coefficient } \\
\text { (std. error) }\end{array}$ \\
\hline $\begin{array}{l}\text { Fraudulent practices in } \\
\text { auction rate securities }\end{array}$ & & $\begin{array}{c}7.37 \\
(11.80)\end{array}$ & $\begin{array}{l}11.20 \\
(10.63)\end{array}$ & - \\
\hline Insider trading & & $\begin{array}{c}36.26 \\
(40.39)\end{array}$ & $\begin{array}{l}27.92 \\
(30.20)\end{array}$ & $\begin{array}{l}24.40 \\
(24.88)\end{array}$ \\
\hline $\begin{array}{l}\text { Insider trading based on } \\
\text { firms' clients' orders }\end{array}$ & & - & - & - \\
\hline Internal control failure & & $\begin{array}{l}-6.60 \\
(17.30)\end{array}$ & $\begin{array}{l}-7.58 \\
(17.41)\end{array}$ & $\begin{array}{l}-34.41 \\
(31.40)\end{array}$ \\
\hline Late trading & & $\begin{array}{l}24.62 \\
(26.46)\end{array}$ & $\begin{array}{l}16.38 \\
(19.81)\end{array}$ & $\begin{array}{l}70.19 * * * \\
17.35\end{array}$ \\
\hline Market manipulation & & $\begin{array}{l}77.16^{* * *} \\
(9.56)\end{array}$ & $\begin{array}{l}64.46^{* * *} \\
(10.16)\end{array}$ & $\begin{array}{l}62.99^{* * *} \\
(12.90)\end{array}$ \\
\hline Market timing & & $\begin{array}{l}19.01 \\
(13.01)\end{array}$ & $\begin{array}{l}19.90 \\
(13.71)\end{array}$ & $\begin{array}{c}30.24 \\
(19.43)\end{array}$ \\
\hline $\begin{array}{l}\text { Misappropriated investor } \\
\text { funds }\end{array}$ & & $\begin{array}{c}38.43 \\
(31.46)\end{array}$ & $\begin{array}{c}30.99 \\
(27.81)\end{array}$ & $\begin{array}{c}33.63 \\
(23.39)\end{array}$ \\
\hline $\begin{array}{l}\text { Obstruction of justice } \\
\text { against SEC members }\end{array}$ & & - & - & - \\
\hline Ponzi scheme & & $\begin{array}{l}83.09^{* * *} \\
(11.15)\end{array}$ & $\begin{array}{l}56.00^{* * *} \\
(14.43)\end{array}$ & $\begin{array}{l}37.43^{* *} \\
(16.28)\end{array}$ \\
\hline Sold unregistered stock & & $\begin{array}{l}96.07^{* * *} \\
(12.21)\end{array}$ & $\begin{array}{l}101.41^{* * *} \\
(12.31)\end{array}$ & $\begin{array}{l}99.56^{* * *} \\
(20.08)\end{array}$ \\
\hline Unauthorized churning & & $\begin{array}{l}11.54 \\
(11.70)\end{array}$ & $\begin{array}{l}19.30 \\
(12.42)\end{array}$ & $\begin{array}{c}34.65 \\
(20.97)\end{array}$ \\
\hline Violation of MSRB rules & & $\begin{array}{l}-0.53 \\
(7.54)\end{array}$ & $\begin{array}{l}-8.70 \\
(8.80)\end{array}$ & $\begin{array}{l}-4.56 \\
(17.33)\end{array}$ \\
\hline Year dummies & Yes & Yes & Yes & Yes \\
\hline $\mathrm{N}$ & 214 & 214 & 214 & 105 \\
\hline
\end{tabular}

${ }^{* * *}$ significant at the 0.01 level, ${ }^{* *}$ significant at the 0.05 level, ${ }^{*}$ significant at the 0.10 level

and fines. Results also suggest that only significant increases in fines could have brought about a moderate reduction in the length of industry ban. For example, Model IV indicates that a doubling of fines against individual employees was associated with an industry ban shorter by just one month. 


\section{Civil Penalties (Fines)}

The analysis of fines ordered in administrative proceedings yields a surprising result: while substantial differences between big and small firms existed for fines ordered against the corporate entity, individuals associated with big and small firms paid similar fines. The average corporate fine in big-firm cases exceeded $\$ 10.2$ million, compared to $\$ 2.3$ million for small firms. Higher corporate fines for big broker-dealers arguably reflected their larger financial resources.

In contrast, big-firm employees in administrative proceedings paid a fine of about $\$ 80,000$ on average, compared to about $\$ 60,000$ for small-firm employees. Fines against big- and small-firm individuals were comparable, regardless of whether their employer was also subject to SEC action. In light of the gap in the length of individuals' industry bans reported above, the similarity in fine levels seems even more noteworthy. The above patterns are confirmed by more detailed regression analysis, not reported here, predicting the level of fines on the basis of firm size, controlling for violation type, disgorgement amounts, and other factors mentioned above. ${ }^{96}$

\section{E. RobustNess CHECKS}

The paragraphs below present additional tests to examine the robustness of the results discussed above. The analysis concentrates on the observed biases in the length of industry bans ordered against individuals associated with big firms in administrative proceedings. These tests show that the differential treatment of big- and small-firm defendants persists even when considering various alternative factors that could explain the SEC's conduct.

The difference in severity of industry bans between big- and small-firm defendants might reflect a selection bias resulting from the SEC's inspection strategy, which provides for regular examinations of the twenty largest firms. While intensively supervising the activities of these very large firms, SEC officials may become aware not only of egregious behavior but also of less significant misconduct, which they may pursue as well. In contrast, cases involving small firms and their employees, not subject to similar levels of oversight, may be more likely to arise from gross misconduct that becomes evident to investors. As noted above, only 10 percent of inspections result in referrals to enforcement staff that may initiate action either in courts or administrative proceedings. To address concerns about selection bias due to inspection practices, the regressions on Table 10 are repeated, but with a sample excluding all cases involving the twenty largest firms, which are inspected on an annual basis. ${ }^{97}$ Model I in Table 10, which presents results for a sample of individuals only, shows that the difference in industry bans between big- and small-firm employees persists.

96. See supra Parts IV.B and IV.C.

97. See GAO REPORT ON RISK-BASEd ExAminations, supra note 33, at 8 . Because the SEC does not disclose the twenty firms it regularly inspects, the list of the top twenty firms is based on their rank according to total equity capital, as included in the SIFMA Yearbooks for each year. 
Since the analysis in Part IV considers as big each firm with 1,000 employees or more, concerns may arise as to whether different measures of firm size affect results. This analysis examines alternative criteria of firm size. First, all firms with 100 employees are classified as big. Results (not shown) do not change. The analysis also considers an alternative criterion of firm size, information on stock exchange listing. All firms that are listed on a U.S. or foreign stock exchange are considered big. Information on whether a firm has a stock exchange listing is available for all firms in the dataset, while data on other measures, such as assets under management or total equity, was available only for a subset of the sample through the SIFMA yearbooks. To the extent available, this data shows that firms with more than 1,000 employees and firms with a stock exchange listing have, on average, higher assets under management and higher total equity than other firms. Model II in Table 10 explores whether defendants associated with listed firms received lower sanctions, repeating the analysis in Table 9 for a subset of individuals. The difference between big- and small-firm defendants persists. ${ }^{98}$

Because big and small firms' operations vary, the violations committed by bigfirm employees could be systematically less egregious than those committed by small-firm employees, even if technically they fall under the same prohibition of the federal securities laws. This concern is the main motivation behind the case study in Part V. Table 10 includes two additional robustness checks. First, the analysis is repeated for a subset of violations defined particularly narrowly, where defendants' conduct should be almost identical. ${ }^{99}$ Model III in Table 10 presents the results of this analysis, limiting the sample to narrowly defined violations committed by individuals. It confirms the difference in industry bans between big- and small-firm employees. Second, Model IV shifts the focus from administrative proceedings to courts and examines whether big-firm employees in civil lawsuits received lower industry bans, compared to small-firm employees. If bigfirm employees committed systematically less egregious violations, we would expect courts to award them lower sanctions as well. However, in contrast with administrative proceedings, results show no difference in industry bans between big- and small-firm employees.

A further possibility is that big-firm defendants, who have repeated interactions with the SEC and receive more sophisticated advice, might show greater willingness to settle with the Commission. As the SEC also seeks to finalize its actions in order to direct enforcement resources elsewhere, it may agree to lower broker-dealer industry bans. To explore the effects of early settlement on a sample of individual employees, Model V includes in the analysis a control of cases in which the parties had pre-agreed to settlement terms and concluded the initiation and completion of the action in a single procedural step. Results show that the difference in industry bans between big- and small-firm employees persists.

98. To examine whether the reported enforcement bias increased as the size of the firm increased, the analysis in Table 9 has been repeated for a subset of defendants associated with listed firms, with the logarithm of market capitalization as a control. Results were not statistically significant.

99. These violations are bribery, failure in best execution duties, failure in supervision, false net capital computation, fraud in auction rate securities, internal control failure, late trading, market timing, obstruction of justice, Ponzi scheme, and sales of unregistered stock. 
Table 10

Robustness Checks

\begin{tabular}{|c|c|c|c|c|c|}
\hline & Model I & Model II & Model III & Model IV & Model V \\
\hline & Exclude Top 20 & Big Based on Listing & Narrow Violations & Bans in Courts & Early Settlement \\
\hline & $\begin{array}{l}\text { Coefficient } \\
\text { (std. error) }\end{array}$ & $\begin{array}{l}\text { Coefficient } \\
\text { (std. error) }\end{array}$ & $\begin{array}{l}\text { Coefficient } \\
\text { (std. error) }\end{array}$ & $\begin{array}{l}\text { Coefficient } \\
\text { (std error) }\end{array}$ & $\begin{array}{l}\text { Coefficient } \\
\text { (std. error) }\end{array}$ \\
\hline Big firm & $\begin{array}{l}-48.69 * * * \\
(17.88)\end{array}$ & $\begin{array}{l}-25.28^{* *} \\
(11.24)\end{array}$ & $\begin{array}{c}-27.48^{*} \\
(14.40)\end{array}$ & $\begin{array}{l}-2.12 \\
(8.89)\end{array}$ & $\begin{array}{c}-19.97^{*} \\
(11.21)\end{array}$ \\
\hline Related proceedings & $\begin{array}{c}-23.00^{* *} \\
(9.67)\end{array}$ & $\begin{array}{c}-20.45^{* *} \\
(8.96)\end{array}$ & $\begin{array}{c}-6.99 \\
(11.15)\end{array}$ & $\begin{array}{l}-21.30^{* *} \\
(10.15)\end{array}$ & $\begin{array}{c}-18.54^{* *} \\
(9.27)\end{array}$ \\
\hline Level of disgorgement & $\begin{array}{c}1.24 \\
(1.15)\end{array}$ & $\begin{array}{c}0.83 \\
(1.19)\end{array}$ & $\begin{array}{c}3.79 * \\
(1.46)\end{array}$ & $\begin{array}{l}3.23^{* * * *} \\
(1.00)\end{array}$ & $\begin{array}{l}1.11 \\
(1.09)\end{array}$ \\
\hline Level of fines & $\begin{array}{l}-2.77^{* * *} \\
(1.03)\end{array}$ & $\begin{array}{l}-3.38^{* * *} \\
(1.09)\end{array}$ & $\begin{array}{c}1.17 \\
(1.43)\end{array}$ & $\begin{array}{c}0.21 \\
(0.52)\end{array}$ & $\begin{array}{l}-3.67^{* * *} \\
(1.09)\end{array}$ \\
\hline Settlement at initiation & & & & & $\begin{array}{l}-24.07 \\
(14.85)\end{array}$ \\
\hline Violation dummies & Yes & Yes & Yes & Yes & Yes \\
\hline Year dummies & Yes & Yes & Yes & Yes & Yes \\
\hline $\mathrm{N}$ & 92 & 105 & 43 & 86 & 105 \\
\hline
\end{tabular}

*** significant at the 0.01 level, ${ }^{* *}$ significant at the 0.05 level, ${ }^{*}$ significant at the 0.10 level 


\section{Systematic Differences Between Big and Small Firms' CONDUCT}

\section{A. Case Study Choice}

The difference in severity of broker-dealer industry bans between big- and small-firm defendants could reflect a systematic difference in the egregiousness of their misconduct not captured by regression controls in the models above. The severity of sanctions could reflect various parameters of the violators' behavior, such as levels of negligence, techniques used to deceive investors, or egregiousness of the violators' fraudulent practices. If big-firm defendants commit acts that are systematically less reproachable than those of small-firm violators, even though they otherwise contravene the same prohibition of the federal securities laws, they should receive lower penalties.

Such systematically dissimilar misconduct by big and small firms could result from differences in their operation, their workforce, and their client base. Big firms operate sophisticated supervision systems to monitor their employees' performance and to ensure quality of service to clients, committing capital and staff to ensure compliance with securities laws. Moreover, big and small firms may differ also in the quality and training of their personnel, as skillful and well-paid traders might be less likely to resort to fraud. Finally, big firms' sophisticated clients are unlikely fraud victims, especially compared to retail investors, who make up small firms' client base. Thus, differences in sanctions between small and big firms could simply reflect their differences in sophistication.

To explore whether there are systematic differences between big and small firms even when violating the same prohibition, the following paragraphs examine qualitatively all violations for a single securities law breach: failure to supervise. This violation presents several advantages for a case study. From a theoretical standpoint, failure to supervise represents the hardest test case. If differences in big and small firms' sanctions reflected differences in firm sophistication not captured by violation types and costs, one would expect these differences to be especially pronounced in violations involving failure to supervise. Big and small firms have very different compliance systems; the case study investigates whether those

Table 11

Average Length of Industry Bars (in Months) for Listed and Non-listed Firms of Similar Size in Administrative Proceedings

\begin{tabular}{lcccc}
\hline & $\begin{array}{c}2007 \text { Revenue in US\$ Mil. } \\
38<\text { firm }>2,000\end{array}$ & $\begin{array}{c}\text { 2007 Revenue in US\$ Mil. } \\
38<\text { firm }>10,000\end{array}$ \\
\cline { 2 - 5 } & $\begin{array}{c}\text { Industry Bar } \\
\text { (Months) }\end{array}$ & Cases & $\begin{array}{c}\text { Industry Bar } \\
\text { (Months) }\end{array}$ & Cases \\
\hline Non-listed firms & 22 & 6 & 22 & 7 \\
Listed firms & 18.18 & 16 & 14.1 & 29 \\
\hline
\end{tabular}


compliance systems led to diverse failures to supervise. Moreover, the number of supervisory failures in the dataset-forty-three defendants in twenty-eight releases-allows for a rich case study with meaningful conclusions. ${ }^{100}$ Finally, the SEC routed the vast majority of supervisory failures to administrative proceedings regardless of whether the perpetrator was associated with a big or a small firm, alleviating concerns that court assignment could systematically bias the pool of violations. ${ }^{101}$ After a brief doctrinal overview, the paragraphs below present summary statistics and discuss patterns of conduct by big and small firms, showing surprising similarities between them.

Either persons or firms can be liable for a failure to supervise, if they fail to prevent a violation of the securities laws by another person who is subject to their supervision. ${ }^{102}$ However, there also exists a safe harbor from liability, which allows supervisors to escape liability if they fulfill the following three conditions. According to the terms of this safe harbor, after establishing that a particular firm or individual is, in fact and in law, a supervisor, the SEC must first examine whether supervisors have established procedures that could reasonably detect and prevent such a violation, i.e., whether they have the requisite rules in compliance manuals and other communications to employees. ${ }^{103}$ Second, the SEC must examine whether supervisors have in place systems implementing those procedures, i.e., whether they prescribe specific measures that supervisory personnel must take in order to ensure that procedures have been followed. ${ }^{104}$ Third, a supervisor will be

Table 12

Supervisory Failures for Big and Small Firms

\begin{tabular}{lccc}
\hline & Big Firms & Small Firms & Total \\
\hline Inadequate procedures cases & 7 & 5 & 12 \\
Inadequate systems cases & 4 & 5 & 9 \\
$\begin{array}{l}\text { Failure to discharge supervisory duties } \\
\text { cases }\end{array}$ & 11 & 10 & 21 \\
$\begin{array}{l}\text { Average industry bars in months } \\
\text { (individuals) }\end{array}$ & 10.5 & 26.2 & - \\
\begin{tabular}{l} 
Average fines (logarithm) \\
\hline
\end{tabular} & 11.06 & 9.30 & - \\
\hline
\end{tabular}

100. This count does not include three additional cases in which the SEC staff brought administrative proceedings for supervisory failures before an Administrative Law Judge, who then found for the defendants and dismissed the cases.

101. Of the forty-three cases, forty-one ended up in administrative proceedings, and only two in courts. See supra Table 1.

102. Securities Exchange Act of 1934 \& 15(b)(4)(E), 15 U.S.C. § 78o(b)(4)(E) (2006 \& Supp. IV 2010).

103. Id. \& 15(b)(4)(E)(i), 15 U.S.C. \& 78o(b)(4)(E)(i).

104. Id. 
deemed to discharge her supervisory obligations when she has diligently performed the tasks assigned to her by the firm's system. ${ }^{105}$

Table 12 shows that all of the above types of supervisory failure include an equal number of big- and small-firm perpetrators. The following paragraphs discuss violations in big and small firms for each type of supervisory failure, demonstrating that deficiencies in oversight are very similar in big and small firms. ${ }^{106}$

\section{B. Inadequate Procedures}

All firms in the sample, however small, had established some compliance infrastructure at the time of the violation, thus alleviating concerns that smaller firms have no supervisory mechanisms. The single case where the failure to adopt supervisory procedures extended over a whole department involved the CEO of a big firm, Stockwalk Group, Inc., whom the SEC found had made no effort to oversee the firm's stock lending unit, resulting in the liquidation of the firm. ${ }^{107}$

Big and small firms were equally deficient in establishing procedures to prevent market timing and late trading in mutual fund stocks. The Commission found that, as a result of lack of procedures, Kaplan \& Co., a small firm, failed to detect the strategies traders used to deceive mutual funds, such as multiple account numbers, multiple registered representative numbers, and multiple office branch codes. ${ }^{108}$ The Commission also found that traders of Southwest Securities, Inc., the brokerage arm of the publicly held SWS Group, Inc., used identical deceptive tactics with the Kaplan traders: multiple account numbers, with multiple customer-affiliated entities as account holders. ${ }^{109}$ The Commission concluded that the firm lacked procedures to detect late trading. ${ }^{110}$

Another common failure for big and small firms relates to supervision of remote or specialized traders. In In re H. Beck, Inc., the Commission found that a nonlisted firm failed to supervise one of its registered representatives who operated independently the firm's Ohio office because it did not require any inspections of independently operated offices. ${ }^{111}$ A publicly held broker-dealer, FSC Securities Corp., had exhibited the same deficiencies. The Commission found that it had failed to subject to any supervision registered representatives who operated as

105. Id. \& $15(\mathrm{~b})(4)(\mathrm{E})(\mathrm{ii}), 15$ U.S.C. $\& 780(\mathrm{~b})(4)(\mathrm{E})(\mathrm{ii})$.

106. The case descriptions below are based on facts as alleged by the SEC in its administrative and litigation releases. Defendants have not necessarily admitted or denied wrongdoing

107. In re Miller, Release No. 34-55024, 89 SEC Docket 2080, 2006 WL 3833001, at *3-4 (Dec. $29,2006)$.

108. In re Kaplan \& Co. Sec., Inc., Release No. 34-54954, 89 SEC Docket 1743, 2006 WL 3718280 , at *3-5 (Dec. 18, 2006).

109. In $r$ Sw. Sec., Inc., Release No. 34-51002, 84 SEC Docket 2316, 2005 WL 43963, at *3-5 (Jan. 10, 2005).

110. Id. at $* 7$

111. In re H. Beck, Inc., Release No. 34-39943, 67 SEC Docket 173, 1998 WL 247663, at *2-3 (May 1, 1998). 
FSC's independent contractors. ${ }^{112}$ Similarly, in In re O'Brien, the SEC found that a big brokerage house, Credit Suisse First Boston, LLC, failed to supervise a trader located in New York who handled all arbitrage trades with Australia because it had established no back office review of trades in Australian stocks and ADRs. ${ }^{113}$ Finally, an ALJ found that Raymond James, a publicly traded brokerage firm, had failed to establish procedures for supervising registered representatives operating independent branches, particularly during a firm-wide restructuring following a merger. ${ }^{114}$

\section{InADEQuate Systems}

Brokerage firms and their managers have been relatively successful in adopting procedures that consist of a basic set of operating rules ensuring compliance with securities laws; however, they have been less effective in establishing adequate implementation systems (i.e., a clearly identified set of tasks and responsibilities that can be easily analyzed by internal audits).

In both big and small firms, lack or inadequacy of review processes often permits "rogue traders" to emerge: a broker-dealer employee organizes fraudulent activities either on her own, or in cooperation with a customer. On the small-firm side, the SEC found that a firm and the CEO did not review whether a trader was abiding by the firm's prohibition from dealing in risky inverse floating collateralized mortgage obligations, despite explicit procedures requiring the CEO's prior approval for such trades. ${ }^{115}$ In another small-firm case, the SEC found that the president of the firm failed to review all daily order tickets, thus permitting a registered representative to execute market manipulation trades on behalf of some hedge funds. ${ }^{116}$

Rogue traders and related review defects in big firms are strikingly similar. The SEC found that a big broker-dealer, First Montauk Financial Corp., prohibited registered representatives from holding long-term positions in mortgage-backed securities without authorization by a supervisor; yet they were able to evade this process because their supervisor failed to review the accuracy of the information he was given. ${ }^{117}$ Big firms are not traditionally implicated in Ponzi schemes; yet, in a case involving the brokerage arm of Fidelity Investments, the mutual fund giant, the SEC sanctioned the president and chief supervisory officer for not establishing a review system for incoming customer correspondence and third-party deposit

112. In re FSC Sec. Corp., Release No. 34-40765, 1998 WL 862516, at *2 (Dec. 9, 1998).

113. In re O'Brien, Release No. 34-51764, 85 SEC Docket 1426, 2005 WL 1287272, at *6-8 (May 31, 2005).

114. In re Raymond James Fin. Servs., Inc., Release No. 34-51090, 84 SEC Docket 2640, 2005 WL 195440, at *9-10 (Jan. 28, 2005).

115. In re Repine, Release No. 34-54937, 89 SEC Docket 1572, 2006 WL 4245602, at *5-6 (Dec. 14, 2006).

116. In re Helblock, Release No. 34-54512, 2006 WL 2738627, at *2-3 (Sept. 26, 2006).

117. In re Cohen, Release No. 34-40450, 68 SEC Docket 90, 1998 WL 640452, at *2-4 (Sept. 18, 1998). 
checks. ${ }^{118}$ Had this system been in place, supervisors would have known that a customer, with support from a registered representative, was constantly writing checks from the account to third parties that had previously deposited checks to that same account. ${ }^{119}$ In another case involving the securities subsidiary of a large insurance group, New York Life Insurance Co., the SEC found that two registered representatives at an off-site branch misappropriated investors' funds. ${ }^{120}$ The SEC found that the firm's supervisory systems were deficient because they provided for daily review of the representatives' activities, but did not include review of the customers' files. ${ }^{121}$

Another characteristic case of system deficiency, common in big and small firms, relates to problems in task delegation to supervisors and lack of instructions. In one case, the Commission found that, although the small firm's compliance manual required review of customer accounts and firm correspondence, the firm and its chairman never provided such instructions or training to supervisors, or examined whether the supervisors were conducting any monitoring. ${ }^{122}$ Similarly, the Commission penalized the president of Vfinance Investments, Inc., the subsidiary of a listed firm, for not implementing Vfinance's supervisory procedures. ${ }^{123}$ The Commission found that Vfinance's system did not identify the persons responsible for supervising traders or the steps to be taken to prevent market manipulation, and that the president of Vfinance never communicated those procedures to supervisory staff. ${ }^{124}$

\section{Failure to Discharge Supervisory Duties}

In half of all supervisory failures in the dataset, the SEC concluded that the broker's management did not respond adequately to indications of wrongdoing by the firm's employees that should have raised suspicions to managers. In an alarming subset of cases, managers received explicit letters of complaint and other documentary evidence from customers, other employees, and even SROs. Time and again, managers in big and small firms alike failed to take any serious measures against the wrongdoer.

Small firms and their managers were often deficient in responding to signals of potential violations by their staff. For example, a registered representative in a small firm concealed trades in high-risk bonds for retail investors by falsifying order tickets to present sales and purchases as occurring in the same day, when

118. In re Hess, Release No. 34-51266, 84 SEC Docket 3265, 2005 WL 464863, at *3 (Feb. 25 , 2005).

119. Id.

120. In re NYLIFE Sec., Inc., Release No. 34-40459, 68 SEC Docket 103, 1998 WL 646712, at*2 (Sept. 23, 1998).

121. Id. at *2-3

122. In re Kaplan \& Co. Sec., Inc., Release No. 34-54954, 89 SEC Docket 1743, 2006 WL 3718280 , at *4 (Dec. 18, 2006)

123. In re Siegel, Release No. 34-51531, 85 SEC Docket 536, 2005 WL 840458, at *2 (Apr. 12, 2005).

124. Id. 
in fact he held the bonds in the customer accounts for months. ${ }^{125}$ The SEC sanctioned the firm's chief executive officer for failing to inquire why, although the sales and purchases always coincided, the representative was earning significant mark-ups. ${ }^{126}$ The circumstances surrounding a manipulative trading scheme in another small-firm case were similar: a representative traded heavily at the last thirty minutes at month end in otherwise thinly traded small-cap stocks to affect the price of the stock. ${ }^{127}$ Again, the Commission found that the president and the head of trading of the firm, as well as the direct supervisor of the trader, ought to have launched an inquiry into the trader's conduct. ${ }^{128}$

Cases involving big firms followed similar patterns of supervisory failures. In the case discussed above regarding a customer operating a Ponzi scheme through a Fidelity Investments brokerage account, the SEC also identified a failure to respond to red flags. ${ }^{129}$ According to the Commission, the president and supervisor of the account, who became aware of third parties depositing checks and receiving payments from the account, and who saw the huge losses on the account, should have taken follow-up actions. ${ }^{130}$ In another case involving a publicly held firm, Suncoast, the trading desk supervisor failed to inquire why the prices charged by a trader to his largest client were significantly marked down and not reasonably related to prevailing market prices, and why the commissions paid to Suncoast were unusually high; in fact, the trader was bribing the client's staff. ${ }^{131}$ Similarly, in a landmark case involving Jefferies \& $C_{0}$., another publicly held broker-dealer, the Commission sanctioned the director of equities for not inquiring why his top-earning registered representative's business originated from just seven traders at Fidelity Investments, given that the representative was allowed a $\$ 1.5$ million entertainment budget. ${ }^{132}$ Hiring private planes and arranging for golf outings amounted to illicit compensation, according to the SEC. ${ }^{133}$ Finally, a branch manager from Raymond James, a publicly held broker-dealer, after realizing that an employee sent false information to investors to attract them to a customer's potentially fraudulent project, did not terminate relationships with them, made no

125. In re Repine, Release No. 34-54937, 89 SEC Docket 1572, 2006 WL 4245602, at *3-4 (Dec. 14, 2006).

126. Id. at *5-6.

127. In re Oakes, Release No. 34-53906, 88 SEC Docket 332, 2006 WL 1490241, at *2 (May 31 , 2006); In re Helblock, Release No. 34-54512, 2006 WL 2738627, at *2 (Sept. 26, 2006); In re Figlioni, Release No. 34-54536, 88 SEC Docket 3085, 2006 WL 2795253, at *2 (Sept. 28, 2006).

128. Oakes, 2006 WL 1490241, at *2-3; Helblock, 2006 WL 2738672, at *3; Figlioni, 2006 WL 2795253, at *2-3.

129. In re Hess, Release No. 34-51266, 84 SEC Docket 3265, 2005 WL 464863, at *2 (Feb. 25, 2005)

130. Id.

131. In re Cohen, Release No. 34-54108, 88 SEC Docket 1115, 2006 WL 1880946, at *2-4 (July 6, 2006).

132. In re Jeffries \& Co., Release No. 34-54861, 89 SEC Docket 1231, 2006 WL 3488900, at *8-11 (Dec. 1, 2006).

133. Id. at *5-6. 
further inquiry into the employee's conduct, and did not take any steps to restrict the employee's activities. ${ }^{134}$

The final set of supervisory failures illustrates that, even when securities violations are explicit, managers in either big or small firms can fail to take disciplinary measures. For example, a managing director and head of financial services at CIBC, a publicly held Canadian company, received over 1,000 letters and e-mails from mutual funds complaining that specific traders engaged in market timing. ${ }^{135}$ In addition, he was aware of actions by those traders that could be used to deceive the funds, such as using multiple accounts. ${ }^{136}$ Yet, he took no action against those traders. ${ }^{137}$ Another publicly held broker-dealer, Southwest Securities, Inc., received letters, emails, and account-blocking notices from thirty-five mutual fund families, representing hundreds of funds, complaining of some traders' market-timing strategies. ${ }^{138}$ Again, no disciplinary action followed. ${ }^{139}$ In the Raymond James case discussed above, compliance officers and management also received a letter of complaint by investors, exposing the trader's misrepresentations. ${ }^{140}$ Moreover, a director of mutual funds sales at the brokerage subsidiary of Credit Suisse First Boston, a publicly held financial group, ignored the compliance department's warnings that a trader did not hold the proper series registration for the type of activities he pursued. ${ }^{141}$

Explicit indications of securities violations can also arise from reports by other departments within the broker-dealer, or from SROs in the securities industry. In a characteristic example, a Salomon Smith Barney analyst assigned unusually favorable "buy" recommendations to stocks issued by clients of the investment banking division of his firm. ${ }^{142}$ Although retail brokers criticized him harshly, other supervisors highlighted the problem in their reports, and he himself mentioned pressure from the investment banking division to his direct supervisors. ${ }^{143}$ These supervisors did not respond to those concerns. ${ }^{144}$ Moreover, the SEC found that disciplinary action by self-regulatory bodies ought to alert managers to their employees' misconduct. The NASD had sanctioned a trader in a small brokerage firm for not adhering by the terms of the offering memorandum regarding unregistered

134. In re Raymond James Fin. Servs., Inc., Release No. 34-51090, 84 SEC Docket 2640, 2005 WL 195440, at *9-10 (Jan. 28, 2005).

135. In re Dornfeld, Release No. 34-55209, 89 SEC Docket 2792, 2007 WL 268278, at *2 (Jan. 31 , 2007).

136. Id at $* 3-4$

137. Id. at *5.

138. In re Sw. Sec., Inc., Release No. 34-51002, 84 SEC Docket 2316, 2005 WL 43963, at *3 (Jan. 10, 2005).

139. Id. at *5-7

140. In re Raymond James Fin. Servs., Inc., Release No. 34-51090, 84 SEC Docket 2640, 2005 WL 195440 , at *6-7 (Jan. 28, 2005).

141. In re Bogard, Release No. 34-40467, 68 SEC Docket 111, 1998 WL 652141, at *3 (Sept. 23, 1998).

142. In re Hoffman, Release No. 34-51713, 85 SEC Docket 1243, 2005 WL 1185530, at *3-4 (May 19, 2005).

143. Id

144. Id. at *4-6. 
partnership interests. ${ }^{145}$ Yet, the managers failed to launch a full inquiry regarding the information in the memorandum, which would have revealed the trader's misrepresentations. ${ }^{146}$ In a similar small-firm case, the SEC sanctioned the brokerdealer's manager for not placing under tight supervision a registered representative with a serious disciplinary past. ${ }^{147}$

\section{Discussion}

The goal of this article is to identify the main elements of the SEC's enforcement strategy toward the broker-dealer industry. The main findings are that when faced with misconduct by big brokerage houses, the Commission relied primarily on corporate liability coupled with high fines, consensual dispute resolution through administrative settlements, and direct negotiations between the agency and the targeted firm without the intervention of a judge. The Commission placed less emphasis on tracking down and expelling from the financial industry individual violators who worked for big brokerage houses.

This account of SEC actions is critical because theorists have engaged in heated debates on enforcement strategies in corporate law, regulatory policy, and public enforcement of securities laws without much data. The discussion that follows spells out some first, tentative implications for three central debates: the choice between individual sanctions and corporate liability in financial misconduct, the exposure of SEC officials to regulatory capture, and the role of public and private enforcement in securities law. While the theories discussed below seek to explain the SEC's enforcement strategy as outlined in Part IV, they do not purport to represent an exhaustive list of potential explanations of the Commission's motives. Rather, they reflect the most vivid concerns raised in connection with the SEC's activity in recent years.

\section{A. Discussion: Individual and Corporate Liability in Financial Misconduct}

Corporate liability, when used in conjunction with actions against individuals, can be a valuable regulatory tool. First, when individual perpetrators' liability vastly exceeds their assets, the corporate coffers are an additional source of funds that could be ultimately directed to harmed investors. Second, corporate liability provides to broker-dealer firms additional incentives to set up proper compliance systems. ${ }^{148}$ SEC actions involving corporate liability often require firms to reform their internal controls, undergo external review, and report back to the Commis-

\footnotetext{
145. In re H. Beck, Inc., Release No. 34-39943, 67 SEC Docket 173, 1998 WL 247663, at *2 (May 1, 1998).

146. Id. at *3.

147. In re Montilla, Release No. 34-40855, 68 SEC Docket 2487, 1998 WL 901756, at *1-2 (Dec. 29 , 1998).

148. See Gary S. Becker, The Economic Approach to Human Behavior 132-38 (1976); Richard PosNER, ECONOMIC ANALYSIS OF LAw 167-72 (2d ed. 1977). For a discussion of regulatory policy outside of the rational actor model familiar from economics, see Michael P. Vandenbergh, Amanda R. Carrico \& Lisa Schultz Bressman, Regulation in the Behavioral Era, 95 MinN. L. Rev. 715 (2011).
} 
sion. ${ }^{149}$ When a violation occurs despite a firm's policies, the SEC might be willing to recognize its efforts by showing some leniency. Corporate liability often attracts significant attention, arguably increasing deterrence.

On the other hand, there is little disagreement among theorists of optimal liability that, in a perfect world, regulators would deter misconduct more successfully by holding each individual responsible for her own actions and forcing her to internalize the costs of her behavior. ${ }^{150}$ In practice, even the most modern, thorough, and well-equipped compliance systems often fail to uncover employee misconduct that perpetrators are actively seeking to conceal. ${ }^{151}$ Moreover, even when corporate compliance mechanisms could successfully identify specific employees as violators, firms may decide to conceal their findings from regulators to avoid further reputational harm or additional government actions. ${ }^{152}$

Balancing corporate liability and individual sanctions presents a puzzle for scholars and regulators alike. Some theories of optimal deterrence have suggested that, in certain cases, sanctions against individual employees may be preferable over corporate liability. This is particularly true when the magnitude of public sanctions available to regulators exceeds any measures that the firm can take against the employee. 153 When the employees of broker-dealer firms engage in misconduct, the harshest sanction they face by their firm is dismissal and public criticism. Typically, however, firms do not reveal the reason behind the dismissal to the employee's former colleagues and to her potential future employers. In contrast, sanctions available to the SEC are significantly more severe. For example, the SEC can ban an individual from the securities industry and require her to look for another line of work. ${ }^{154}$ Moreover, while securities professionals may be able to pass on financial penalties to their employers through indemnification agreements, ${ }^{155}$ they must suffer the consequences of an industry ban on their

149. See supra note 51 and accompanying text.

150. See William T. Allen, Commentary on the Limits of Compensation and Deterrence in Legal Remedies, 60 Law \& Contemp. Probs. 67, 80 (1997); Jennifer Arlen \& Reinier Kraakman, Controlling Corporate Misconduct: An Analysis of Corporate Liability Regimes, 72 N.Y.U. L. REv. 687, 695 (1997); see generally Miriam H. Baer, Linhage and the Deterrence of Corporate Fraud, 94 VA. L. Rev. 1295 (2008); Robert Cooter \& Melvin A. Eisenberg, Fairness, Character, and Efficiency in Firms, 149 U. PA. L. Rev. 1717 (2001); Louis Kaplow, Optimal Deterrence, Uninformed Individuals, and Acquiring Information About Whether Acts Are Subject to Sanctions, 6 J.L. ECON. \& ORG. 93 (1990); Andrew F. Tuch, Multiple Gatekeepers, 96 VA. L. REv. 1583 (2010).

151. See John C. Coffee, Jr., "No Soul to Damn: No Body to Kick": An Unscandalized Inquiry into the Problem of Corporate Punishment, 79 MicH. L. Rev. 386, 394 (1981); but see Marcel Kahan \& Edward Rock, Embattled CEOs, 88 TEx. L. REv. 987 (2010) (arguing that the CEOs of public U.S. corporations are losing power).

152. See Jennifer Arlen, The Potentially Perverse Effects of Corporate Criminal Liability, 23 J. LEGAL STUD. 833, 835 (1994)

153. See A. Mitchell Polinsky \& Steven Shavell, Should Employees Be Subject to Fines and Imprisonment Given the Existence of Corporate Liability?, 13 InT'L REv. L. \& ECON. 239 (1993).

154. Banned individuals might suffer a significant reputation hit, as well as a drop in their earnings. For a discussion of pay practices in the financial industry in relation to the 2007-2008 crisis, see Lucian A. Bebchuk \& Holger Spamann, Regulating Bankers' Pay, 98 Geo. L.J. 247 (2010); Lucian A. Bebchuk, Alma Cohen \& Holger Spamann, The Wages of Failure: Executive Compensation at Bear Stearns and Lehman 2000-2008, 27 YALE J. ON REG. 257 (2010).

155. Typically, indemnification agreements exclude instances where employees are found to have acted with scienter, as in most securities violations. However, in SEC settlements individuals often admit no wrongdoing and thus the question of scienter remains unresolved. As a result, individuals 
own. These concerns should give us pause for thought when evaluating the SEC's choices in favor of corporate liability alone.

\section{B. Discussion: Concerns About Regulatory Capture}

The 2008 financial collapse and the Madoff affair have reinforced concerns about a "privileged" relationship between well-known Wall Street firms and the SEC, as well as the federal government more generally. Some are worried that the SEC may show particular deference toward a small group of elite Wall Street firms, either because of their high prestige and reputation, or because of their political connections. ${ }^{156}$ If this were true, cases involving such firms should receive significantly more favorable treatment compared to other cases in the dataset. However, the data presented in this article does not offer much support to these concerns, since the distribution of industry ban length in SEC administrative proceedings shows few outliers among big firms. That is, the models in Table 9 above show that the actual sanctions against big-firm employees align well with sanctions we would predict based on firm size, type of violation, disgorgement amount, and other factors. The outliers I do observe are not concentrated among very prominent firms. Instead, unusual sanctions appeared in cases in which defendants were unwilling to settle with the SEC. In summary, the empirical patterns outlined above do not appear to be the product of small sanctions against a few high-profile firms. Instead, they appear to result from systematic differences in enforcement outcomes between big- and small-firm employees.

Concerns about systematic patterns in the SEC's enforcement process raised by practitioners and academics have focused on two aspects of SEC officials' interaction with the industry they monitor. The first concern is that the SEC has limited bureaucratic resources, and thus might be willing to accept a less aggressive settlement against defendants with sophisticated legal teams in order to turn its attention to other cases. While the financial industry has seen tremendous growth in the last decade, SEC staff levels have remained stable. ${ }^{157} \mathrm{~A}$ series of GAO reports have highlighted the SEC's resource constraints, particularly with regard to the agency's enforcement operations. ${ }^{158}$ Such resource constraints could

may claim indemnification by their employers or insurers. See John C. Coffee, Jr., Reforming the Securities Class Action: An Essay on Deterrence and Its Implementation, 106 Colum. L. REv. 1534, 1568 (2006).

156. See Michael Lewis \& David Einhorn, The End of the Financial World as We Know It, N.Y. TimfS, Jan. 4, 2009, at WK9 (suggesting that the SEC "has somehow evolved into a mechanism for protecting financial predators with political clout from investors").

157. See, e.g., Mary Schapiro, Chairman, U.S. Sec. \& Exch. Comm'n, Testimony Before the Subcommittee on Financial Services and General Government, Committee on Appropriations, U.S. House of Representatives (Mar. 11, 2009), available at http://www.sec.gov/news/testimony/2009/ts031109mls. htm; Arthur Levitt, Jr., How the SEC Can Prevent More Madoffs, WAll Sr. J., Jan. 5, 2009, at A13.

158. See, e.g., U.S. Gov't Accountabiltry Office, SEC Operations: InCREASEd Workload Creates ChalLENGES 11-13 (2002), available at hitp:/www.gao.gov/assets/240/233927.pdf [hereinafter SEC OPERAtions Report]; U.S. Gov't Accountabiluty Office, SEC and CFTC Penalties: Continued Progress Made in Collection Efforts, but Greater SEC Management Attention Is Needed 33-34 (2005), available at http://www.gao.gov/assets/250/247566.pdf. 
influence the SEC's enforcement strategy. SEC officials might prefer to settle a case early and continue on to a different matter, rather than engage in litigation that could yield tougher sanctions but require more of their time and effort. ${ }^{159}$ Moreover, overworked SEC officials might prefer smaller and more manageable cases to complicated scenarios or cases in which regulatory standards are vague. ${ }^{160}$ Indeed, this study confirms that the SEC settled the vast majority of cases in the area of broker-dealer regulation, particularly the more complex ones, and tended to bring small cases. ${ }^{161}$

A second concern raised in the literature is that SEC officials may show favoritism toward important broker-dealers, either because they seek to increase their chances of finding future industry employment, or because they have come to share the industry's perspective. Of all regulatory officials in the SEC at the beginning of $2007,8.6$ percent had left the agency by that year's end. ${ }^{162}$ Approximately one-third of SEC staff left the agency between 1998 and 2000. ${ }^{163}$ Almost half of all SEC officials intend to stay with the agency for less than five years in aggregate, while only 9 percent would consider spending their entire career at the SEC. ${ }^{164}$ More than half of all SEC employees were employed in the private sector before joining the agency, either in broker-dealer firms or in firms offering advice and other services to broker-dealers, such as law firms and accounting firms. ${ }^{165} \mathrm{On}$ average, SEC officials earn 50 percent less than employees in comparable positions in the private sector. ${ }^{166}$ Since private sector employment is central to SEC officials' professional origins and future moves, it could affect their conduct in the enforcement proceedings through various channels. In regulatory capture models, ${ }^{167}$ post-agency employment at higher salaries may operate as a quid pro quo in return for favorable regulatory treatment. Even in the absence of a direct promise for future employment, Commission officials might find the personal connections developed during their time in public service valuable, either as direct links to prospective employers, or as a credible source of information for other employers. The "revolving door" between an agency and the industry it supervises may also affect regulatory performance through socialization mechanisms. ${ }^{168}$ Theorists

\footnotetext{
159. SEC OPERATIONS REPORT, supra note 158 , at 11-12.

160. Id. at 19 .

161. For example, of the 347 SEC releases examined to build the dataset, only thirteen involved more than three different defendants.

162. See 2007 Performance AND ACCOUNTABILITY RePORT, supra note 67, at 42.

163. See U.S. Gov't Accountability Office, Securities and Exchange Commission: Human Capital ChalLENGES Require MANAGEMENT ATtention 1 (2001), available at http://www.gao.gov/assets/240/232683. pdf.

164. See id. at 37.

165. See id at 49 .

166. See id. at 2 .

167. See, e.g., Jean Tirole, Hierarchies and Bureaucracies: On the Role of Collusion in Organizations, 2 J.L. ECON. \& ORG. 181 (1986).

168. For discussions of how socialization works, see, among others, Ryan Goodman \& Derek Jinks, How to Influence States: Socialization and International Human Rights Law, 54 DuKE L.J. 621 (2004); Charles K. Whitehead, What's Your Sign?-International Norms, Signals, and Compliance, $27 \mathrm{MrCH}$. J. INT'L L. 695, 709-10 (2006); and Katerina Linos, Diffusion Through Democracy, 55 AM. J. PoL. Sal 678 (2011).
} 
have long argued that regulators with industry origins have become "socialized" toward that industry's concerns and aspirations, carrying that perspective into their regulatory tasks. Scholars have identified such influence in the policymaking decisions of FCC Commissioners, ${ }^{169}$ central bankers, ${ }^{170}$ and state insurance commissioners. ${ }^{171}$

At present, publicly available data only takes us part of the way toward understanding SEC enforcement patterns. Direct tests of the regulatory capture and resource constraints hypotheses are not possible because the SEC releases following a settlement in administrative proceedings do not consistently reveal either the inhouse and outside lawyers who represented the respondents, or the SEC officials who handled the action. ${ }^{172}$ As a result, it is currently impossible to identify conclusively whether SEC officials who subsequently left the agency were more likely to be involved in cases with lower sanctions. Similarly, there can be no empirical assessment of the effect of superior legal representation on case outcomes. In civil court actions, the SEC readily discloses the names and positions of the key officials representing the Commission in the litigation, even when the action results in a settlement. Administrative proceedings should guarantee comparable levels of transparency to the investing public, especially since the SEC's sanctioning powers are extensive. If the SEC disclosed the identities of the officials involved in administrative proceedings, researchers would be able to examine empirically whether revolving doors or resource constraints influence case outcomes. Arguably, additional disclosure may limit the discretion of SEC employees when deciding whether to bring a case or to close a case without enforcement action, as these decisions may affect their professional reputation. Yet, this additional information will establish an additional layer of public oversight over the SEC's settlement decisions. Thus, it can help increase accountability and restore market confidence in the SEC as an effective enforcer of U.S. securities laws.

\section{Discussion: Public and Private Enforcement of SeCurities Laws}

Theorists in economics and law have long debated whether a public regulator is necessary for effective enforcement of securities laws, or whether investors can better ensure compliance through private rights of action. Since this debate

169. See William T. Gormley, Jr., A Test of the Revolving Door Hypothesis at the FCC, 23 Am. J. PoL. SCI. 665 (1979); Ross D. Eckert, The Life Cycle of Regulatory Commissioners, 24 J.L. \& ECoN. 113 (1984); Jeffrey E. Cohen, The Dynamics of the "Revolving Door" on the FCC, 30 AM. J. PoL. SCl. 689 (1986).

170. See Christopher A. Adolph, The Dilemma of Discretion: Career Ambition and the Politics of Central Banking (2004) (unpublished Ph.D. dissertation, Harvard University) (on file with The Business Lawyer).

171. See Martin F. Grace \& Richard D. Phillips, Regulator Performance, Regulatory Environment and Outcomes: An Examination of Insurance Regulator Career Incentives on State Insurance Markets, 32 J. BANKING \& Fin. 116 (2008).

172. Sometimes, the SEC includes the identities of some of these parties in news excerpts included in the SEC Digest. Unfortunately this policy is not systematic, at least not in the period covered in this article's dataset, and thus it cannot provide sufficient data for the purposes of hypotheses testing. Moreover, this policy typically does not include the identity of the senior staff members whose views 
hinges on how public and private enforcement mechanisms perform in practice, scholars have turned to empirical work to understand better the actual strengths and weaknesses of these enforcement paradigms.

A first set of studies examines cross-national variation in the formal legal design of enforcement regimes. These studies report that those countries whose securities laws provide well-specified liability standards enforceable through private rights of action have larger and more liquid capital markets. ${ }^{173}$ However, these studies find that public enforcement's role in fostering capital market growth is modest. ${ }^{174}$ Other research in banking supervision reaches a similar conclusion emphasizing the importance of private enforcement mechanisms. ${ }^{175}$ Yet, these studies share a major limitation: they categorize jurisdictions based on their laws "on the books," rather than their "laws in action." ${ }^{176}$ As other researchers emphasize, similarly designed private enforcement mechanisms, such as those of the United States and the United Kingdom, can result in very different numbers of actions brought by investors and in very different levels of damages awarded. ${ }^{177}$

As a result, subsequent studies delve deeper in examining how private investors and public regulators utilize the powers granted to them by law. A recent cross-national study looked at actual resources devoted to public enforcement mechanisms, such as regulators' budgets and staff memberships. This data yielded a different conclusion: countries that spend more in public enforcement also experience better capital market outcomes. ${ }^{178}$

But how exactly do regulators utilize the powers, resources, and staff granted to them by legislators? This article represents the next empirical step in understanding how public enforcement works in practice, by examining in greater detail how U.S. regulators carry out their enforcement mission. It demonstrates how active the SEC has been toward the securities industry, describing the defendants targeted, the violations pursued, the settlements agreed, and the sanctions sought. However, the article also brings to light the U.S. regime's successes and limitations. This portrayal helps move the debate away from a theoretical discussion based on idealized-or demonized-views of public enforcement, toward a realworld account of a U.S. regulator. Finally, it explains what additional information

carry the most weight in settlement negotiations. However, it suggests that the SEC may not be withholding this information intentionally, and therefore may be open to the proposed disclosure.

173. See La Porta, Lopez-De-Silanes \& Shleifer, supra note 28, at 14-23.

174. See id.

175. See James R. Barth, Gerard Caprio Jr. \& Ross Levine, Bank Regulation and Supervision: What Works Best?, 13 J. Fin. Intermediation 205, 245 (2004).

176. For a similar critique, see Chris Brummer, How International Financial Law Works (and How It Doesn't), 99 GEo. L.J. 257, 272-73 (2011) (discussing the importance of studying both securities laws on the book and securities laws as enforced)

177. See John Armour, Bernard Black, Brian Cheffins \& Richard Nolan, Private Enforcement of Corporate Law: An Empirical Comparison of the United Kingdom and the United States, 6 J. EMPIRICAL LEGAL Stud. 687 (2009); see also Pierre-Henri Conac, Luca Enriques \& Martin Gelter, Constraining Dominant Shareholders' Self-Dealing: The Legal Framework in France, Germany, and ltaly, 4 EUR. CO. \& FIN. L. REV. 491 (2007); Daniel M. Klerman, Paul G. Mahoney, Holger Spamann \& Mark 1. Weinstein, Legal Origin or Colonial History?, 3 J. Legal Analysis 379 (2011).

178. See Jackson \& Roe, supra note 30 , at $237-38$ 
is necessary in order to reach a complete assessment of the SEC as a public enforcer.

\section{Conclusion}

This article offers the first comprehensive empirical account of SEC supervision of broker-dealers. It uses a new dataset of SEC enforcement actions against brokerdealers in courts and administrative proceedings during 1998, 2005, 2006, and the first four months of 2007. The analysis shows that big-firm defendants fared better in three ways. First, when big firms and their staff were engaged in misconduct, the SEC often brought actions based exclusively on corporate liability, without naming any specific individuals as defendants. Second, for the same violation and comparable levels of harm to investors, big firms and their employees were less likely than small firms and their employees to end up in court rather than in an administrative proceeding; in courts, the likelihood of a ban from the broker-dealer industry was higher. Third, among cases that the SEC assigned to administrative proceedings, big-firm defendants were more likely than small-firm defendants to receive no industry ban, controlling for violation type and harm to investors. The gap between big and small firms persists when the analysis is limited to the individual employees of such firms. As discussed in Part VI above, these findings have significant implications for theoretical debates regarding corporate liability, regulatory capture, and the public and private enforcement of securities laws. 